\title{
Taxonomic revision of the genus Elmomorphus Sharp, 1888 I. Japanese and Korean species (Coleoptera: Dryopidae)
}

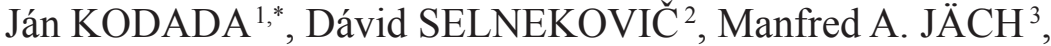 \\ Katarína GOFFOVÁ ${ }^{4}$ \& Peter VĎAČNÝ $\odot 5$ \\ 1,2,4,5 Department of Zoology, Faculty of Natural Sciences, Comenius University in Bratislava, \\ Mlynská dolina B-1, SK-842 15 Bratislava, Slovakia. \\ ${ }^{3}$ Naturhistorisches Museum Wien, Burgring 7, A-1010 Wien, Austria. \\ ${ }^{*}$ Corresponding author: jan.kodada@uniba.sk \\ ${ }^{2}$ Email: david.selnekovic@uniba.sk \\ ${ }^{3}$ Email: manfred.jaech@nhm-wien.ac.at \\ ${ }^{4}$ Email: katarina.goffova@uniba.sk \\ ${ }^{5}$ Email: peter.vdacny@uniba.sk \\ ${ }^{1}$ urn:lsid:zoobank.org:author:6E88BFBB-8769-44EC-8285-29E357CEC064
${ }^{2}$ urn:lsid:zoobank.org:author:D930D757-D929-4248-A29C-A857E0505345
${ }^{3}$ urn:1sid:zoobank.org:author:D749707A-8823-4110-8D51-BF5AF4E2820F
${ }^{4}$ urn:lsid:zoobank.org:author:4AE3FEFE-E697-43CE-844B-25609A9C0DB1
${ }^{5}$ urn:lsid:zoobank.org:author:47A28E80-E04F-40C4-93A3-F7F685C9533A
}

\begin{abstract}
The species of Elmomorphus Sharp, 1888 occurring in Japan and Korea are redescribed and illustrated: E. brevicornis Sharp, 1888 (Japan, Korea) and E. amamiensis Nomura, 1959 (Japan). The standard barcoding fragment of the mitochondrial gene coding for cytochrome $c$ oxidase subunit I(COI) was sequenced and used together with morphological characters to delimit the taxonomic boundaries of the two species. To assess their morphometric variation, eight morphometric characters were measured and statistically evaluated using principal component analysis. The two species of Elmomorphus formed distinct and well-separated clusters in the COI tree. Their interspecific divergence is very high, ranging from 22.7 to $23.9 \%$. On the other hand, morphometric characters, including those previously presumed to be diagnostic, overlap and per se do not allow unambiguous species identification. Reliable morphological distinguishing characters are described for males and females. Molecular data along with the morphological evidence strongly confirm the species status of E. amamiensis. An identification key to the Japanese and Korean species is provided.
\end{abstract}

Keywords. Long-toed water beetles, COI barcoding, integrative taxonomy.

Kodada J., Selnekovič D., Jäch M.A., Goffová K. \& Vd’ačný P. 2021. Taxonomic revision of the genus Elmomorphus Sharp, 1888 I. Japanese and Korean species (Coleoptera: Dryopidae). European Journal of Taxonomy 758: 97121. https://doi.org/10.5852/ejt.2021.758.1427 


\section{Introduction}

The genus Elmomorphus Sharp, 1888 was described by the renowned British coleopterist David Sharp (1840-1922) based on E. brevicornis Sharp, 1888 from Japan. Over the next 130 years, another 17 species were added, mainly from the Oriental Region.

The species of the genus Elmomorphus are regarded as True Water Beetles (Jäch 1998; Jäch \& Balke 2008). They spend most of their life span submerged in various running water habitats. Most species prefer streams and rivulets flowing through forested areas. Immature adults undertake dispersal flights and are often collected in large numbers at light, at least the widely distributed and common species in Southeast Asia. However, there are numerous undescribed species, especially those living in primary rainforests (e.g., in Borneo), which were never collected at light, even if light traps were exposed near streams inhabited by large Elmomorphus populations.

Concerning the fauna of Japan, the family Dryopidae Billberg, 1820 is represented by four species: Elmomorphus brevicornis Sharp, 1888 (type species), E. amamiensis Nomura, 1959, Helichus ussuriensis Lafer, 1980 and the recently recorded and obviously introduced Dryops nitidulus (Heer, 1841) (Yoshitomi \& Haga 2018; Nakajima et al. 2020). As for Korea, only one dryopid species, E. brevicornis, has been recorded so far (Jung \& Bae 2014; Kodada \& Jäch 2016).

Due to the remarkable morphological similarity, E. amamiensis was initially described as a subspecies of $E$. brevicornis by Nomura (1959) from Amami Island in the Ryukyu Archipelago. The specific status was proposed recently by Jung \& Bae (2014), referring to several more or less evident morphological characters.

We examined the type material of E. brevicornis housed in the Sharp collection in the Natural History Museum London and additional material, including freshly collected specimens of both taxa from Japan. Using an integrative taxonomic approach, we redescribe, illustrate, and diagnose E. brevicornis and $E$. amamiensis, and provide reliable morphological distinguishing characters for both sexes.

This publication is the first part of a comprehensive taxonomic revision of the genus Elmomorphus. The second part (in prep.) will deal with the Chinese species, and it will include a thorough morphological redescription of the genus. The final parts will deal with the species of the Oriental and Australian regions. The revision of Elmomorphus started in the 1990s, but due to the ever-growing number of specimens and new species collected, its publication has been retarded.

\section{Material and methods}

\section{Taxonomic methods}

The material examined in this study is deposited in the Natural History Museum London, United Kingdom (NHMUK), Naturhistorisches Museum Wien, Austria (NHMW), and the Ján Kodada collection, Comenius University in Bratislava, Slovakia (JKCB).

Dry specimens were firstly relaxed for several hours in water with several drops of concentrated acetic acid. Male genitalia were dissected, cleared in lactic acid for one or two days, and temporarily mounted on a microscope slide with a single cavity in Berlese's fluid (Swan 1936). After examination/drawing, the male genitalia were mounted in a drop of DMHF on the same card as the respective specimen. Female genitalia were observed in glycerol and stored in micro-vials filled with glycerol and pinned under the studied specimen. Examination and dissection were made under a Leica MZ16 stereo microscope with magnifications up to $120 \times$ and a diffuse LED lighting. Drawings were hand-made with a pencil, using a drawing device attached to a Leica DM 1000 microscope and subsequently traced in Adobe 
Illustrator CC. The specimens were photographed under a Zeiss Axio-Zoom V-16 stereo microscope and a Canon 5D Mark IV camera attached. Each habitus photography was created by stacking 100-120 focal planes using the software ZereneStacker (https://zerenesystems.com/cms/stacker).

For scanning electron microscopy, specimens were dehydrated in graded ethanol series and air-dried from absolute ethanol, coated with gold, and then viewed in a TESCAN microscope.

Label data are cited verbatim, enclosed within quotation marks; individual labels are separated by a vertical bar; square brackets enclose additional information.

The morphological terminology is primarily based on Kodada et al. (2016) with some additions.

Measurements were made under a Leica MZ16 stereo microscope with Leica eyepiece cross micrometre ( $5: 100)$. In total, 12 morphometric characters, as listed in the 'Abbreviations' section below, were scored on 37 specimens. The range of measured values and ratios is followed by mean, standard deviation, and the number of individuals measured.

Principal component analysis (PCA) was conducted on eight morphometric characters: PL, PW, EL, EW, PrTL, MsTL, MtTL, and ID. Datasets were compiled separately for both sexes and included 14 males and seven females of E. brevicornis, and nine males and seven females of E. amamiensis. Data were logtransformed before the analysis, and a variance-covariance matrix was used for the subsequent calculations. Several specimens used for DNA isolation were also included in the datasets. The analysis was performed in the PAST 3.12 software (Hammer et al. 2001). Plots were edited in Adobe Illustrator CC.

\section{Molecular methods}

Eight specimens of E. amamiensis and 16 specimens of E. brevicornis from Japan, fixed in $96 \%$ ethanol were used for molecular analyses. Unfortunately, no specimens from Korea were available. Tissue samples contained either one leg with coxa and attached muscle, or the entire abdomen of an adult specimen. DNA was isolated with the E.Z.N.A. ${ }^{\circledR}$ Tissue DNA kit (OMEGA Bio-tek Inc., Norcross, GA, USA) according to the manufacturer's protocol. The 5' end of the mitochondrial gene coding for cytochrome $c$ oxidase subunit I (COI), the standard barcode (Hebert et al. 2003), was PCR amplified with the standard primers LCO1490 and HCO2198 (Folmer et al. 1994). Individual PCR reactions were conducted in a total volume of $15 \mu \mathrm{l}$ and included $6.67 \mu \mathrm{l}$ of GoTaq ${ }^{\circledR}$ Green master mix (Promega, Fitchburg, WI, USA), $0.34 \mu \mathrm{l}$ of each primer ( $10 \mathrm{pmol} / \mu \mathrm{l}), 50 \mathrm{ng}$ of template DNA, and $4.65 \mu 1$ nucleasefree water. The PCR thermocycler program was as follows: $94^{\circ} \mathrm{C}$ for $180 \mathrm{~s}, 40$ cycles of $94^{\circ} \mathrm{C}$ for $40 \mathrm{~s}$, $52^{\circ} \mathrm{C}$ for $40 \mathrm{~s}$, and $72^{\circ} \mathrm{C}$ for $60 \mathrm{~s}$, and $72^{\circ} \mathrm{C}$ for $10 \mathrm{~min}$. PCR products were extracted from the $1 \% \mathrm{TBE}$ agarose gel, using the Exo-CIP ${ }^{\mathrm{TM}}$ Rapid PCR Cleanup Kit (New England Biolabs ${ }^{\circledR}$ Inc., Ipswich, MA, USA) according to the manufacturer's protocol. Purified PCR products were sequenced from both sides in Macrogen Europe B.V. (Amsterdam, Netherlands). Sequences were trimmed and assembled into contigs in Geneious ver. 6.1 .8 (https://www.geneious.com).

\section{Phylogenetic methods}

The nucleotide COI sequences were aligned based on the predicted amino acid sequences with MEGA-X (Kumar et al. 2018), using the invertebrate mitochondrial genetic code and the MUSCLE codon algorithm. COI sequences of Pomatinus substriatus (Müller, 1806) and Dryops auriculatus (Geoffroy, 1785) were retrieved from the GenBank database (https://www.ncbi.nlm.nih.gov/genbank/) and served as outgroup. Their accession numbers are specified in the respective figure.

Three algorithms were used to infer phylogenetic relationships and to confirm the consistency of the results. A maximum likelihood tree was constructed with the program IQTree (Nguyen et al. 2015) on 
XSEDE ver. 1.6.10, using the CIPRES science gateway ver. 3.3 (http://www.phylo.org/) (Miller et al. 2010). The best fitting evolutionary substitution model was determined with the aid of the BIC criterion, using the in-built ModelFinder program. The maximum likelihood analyses included the BioNJ tree option to build the starting tree, correction for ascertainment bias, 1000 ultrafast bootstrap replicates to assess the reliability of internal nodes, and the bnni algorithm to reduce overestimating support (Hoang et al. 2018). Bayesian inference was carried out in the program MrBayes (Ronquist et al. 2012) on XSEDE ver. 3.2.7 under the best evolutionary substitution model, as selected with the BIC criterion in jModelTest ver. 2.1.10 (Darriba et al. 2012). Markov Chain Monte Carlo (MCMC) simulations included two independent runs each with four simultaneous chains, one million generations, a sampling frequency of trees and parameters at one hundred, and a burn-in fraction at $25 \%$. Convergence of the MCMC analyses to stationary distribution and an adequate sample from the posterior distribution were confirmed using the in-built MrBayes diagnostics. Finally, a distance neighbour-joining (NJ) tree was constructed with the maximum composite likelihood method, gamma distributed rates among sites $(\alpha=0.5)$, and heterogenous patterns among lineages. The reliability of nodes in the distance tree was assessed with 1000 bootstrap pseudo-replicates. All trees were computed as unrooted and were rooted a posteriori using the outgroup taxa in FigTree ver. 1.2.3 (http://tree.bio.ed.ac.uk/software/figtree/).

For the barcoding analyses, pairwise $p$-distances were calculated in MEGA-X (Kumar et al. 2018). Histograms showing the intraspecific, interspecific as well as the intergeneric distances were prepared in Python ver. 3.6.6, using the libraries scikit-learn (Pedregosa et al. 2011) and Matplotlib (Hunter 2007). Multidimensional scaling (MDS) was carried out on the pairwise $p$-distances with the scikitlearn library. The ordination MDS diagram was constructed with the metric technique, the SMACOF algorithm, and 250 initializations, whereby each initialization had 20000 iterations, and $\varepsilon$ was set to $10^{-8}$ to declare convergence.

A haplotype network was calculated from the COI alignment using the TCS method (Clement et al. 2000) in PopART ver. 1.7 (Leigh \& Bryant 2015). Mutations were displayed as numbers along the network edges.

\section{Abbreviations}

$\mathrm{APD}=$ linear distance between anterior angles of pronotum in dorsal aspect

$\mathrm{EL}=$ elytral length from the middle of the anterior margin of the scutellum (scutellary shield) to the apex of the elytra

$\mathrm{EW}=$ greatest width of elytra in dorsal aspect

ID $=$ minimum linear distance between eyes in dorsal aspect

MsTL = maximum length of mesotibia

$\mathrm{MtTL}=$ maximum length of metatibia

$\mathrm{PhL}=$ greatest linear distance between base and apex of phallobase in the lateral aspect

$\mathrm{PL}=$ pronotal length along the midline

$\operatorname{PrL}=$ greatest linear distance between base and apex of parameres in the lateral aspect

PrTL = maximum length of protibia

$\mathrm{PW}=$ maximum pronotal width

$\mathrm{TL}=$ linear distance between the anterior margin of the pronotum and the apex of the elytra along the midline

\section{Results}

\section{Phylogenetic analyses}

Nineteen new COI sequences were obtained from two species of Elmomorphus; seven sequences from E. amamiensis and 12 sequences from E. brevicornis. Their origin and GenBank accession numbers are 
KODADA J. et al., Revision of Elmomorphus - Japanese and Korean species

Table 1. Origin and GenBank accession numbers of COI sequences used in phylogenetic analyses.

\begin{tabular}{lll}
\hline Sample code & Locality & GenBank no. \\
\hline Elmomorphus amamiensis_JK217 & JAPAN, Kagoshima Pref., Amami Island & MW036754 \\
Elmomorphus amamiensis_JK218 & JAPAN, Kagoshima Pref., Amami Island & MW036755 \\
Elmomorphus amamiensis_JK220 & JAPAN, Kagoshima Pref., Amami Island & MW036756 \\
Elmomorphus amamiensis_JK221 & JAPAN, Kagoshima Pref., Amami Island & MW036757 \\
Elmomorphus amamiensis_JK222 & JAPAN, Kagoshima Pref., Amami Island & MW036758 \\
Elmomorphus amamiensis_JK223 & JAPAN, Kagoshima Pref., Amami Island & MW036759 \\
Elmomorphus amamiensis_JK224 & JAPAN, Kagoshima Pref., Amami Island & MW036760 \\
Elmomorphus brevicornis_JK226 & JAPAN, Shimane Pref., Matsue, Yakumo & MW036761 \\
Elmomorphus brevicornis_JK227 & JAPAN, Shimane Pref., Matsue, Yakumo & MW036762 \\
Elmomorphus brevicornis_JK228 & JAPAN, Shimane Pref., Matsue, Yakumo & MW036763 \\
Elmomorphus brevicornis_JK229 & JAPAN, Shimane Pref., Matsue, Yakumo & MW036764 \\
Elmomorphus brevicornis_JK230 & JAPAN, Shimane Pref., Matsue, Yakumo & MW036765 \\
Elmomorphus brevicornis_JK231 & JAPAN, Shimane Pref., Matsue, Yakumo & MW036766 \\
Elmomorphus brevicornis_JK232 & JAPAN, Shimane Pref., Matsue, Yakumo & MW036767 \\
Elmomorphus brevicornis_JK233 & JAPAN, Shimane Pref., Izumo, Nishitani & MW036768 \\
Elmomorphus brevicornis_JK234 & JAPAN, Shimane Pref., Izumo, Nishitani & MW036769 \\
Elmomorphus brevicornis_JK235 & JAPAN, Shimane Pref., Izumo, Nishitani & MW036770 \\
Elmomorphus brevicornis_JK236 & JAPAN, Shimane Pref., Izumo, Nishitani & MW036771 \\
Elmomorphus brevicornis_JK237 & JAPAN, Shimane Pref., Izumo, Nishitani & MW036772 \\
Pomatinus substriatus & GERMANY, Bavaria, Isen River near Oberdorfen & KM445386.1 \\
Pomatinus substriatus & FRANCE, Durance River & MF458799.1 \\
Dryops auriculatus & GERMANY, Saxony-Anhalt, Huy north of Athenstedt & KW906802.1 \\
Dryops auriculatus & GERMANY, Saxony-Anhalt, Huy north of Athenstedt & KU918229.1 \\
\hline & & \\
\hline
\end{tabular}

summarised in Table 1. Three phylogenetic methods (IQTree, MrBayes, and NJ) were utilised to delimit their taxonomic boundaries and reconstruct their interrelationships. All algorithms brought almost identical results and, therefore, only the maximum likelihood IQTree is presented along with nodal supports from all three statistical methods (Fig. 1A). The two species of Elmomorphus formed strongly to fully statistically supported clusters that were separated by long branches in the COI trees. Despite their deep divergence, E. amamiensis and E. brevicornis grouped with very strong statistical support (98\% IQTrees, 1.00 MrBayes, 97\% NJ). Their monophyletic origin was recognized not only when the trees were rooted by outgroup taxa, but also when the midpoint rooting method was applied.

The distinctness as well as the deep divergence of the two species of Elmomorphus were also corroborated by barcoding analyses and multidimensional scaling. The intraspecific distances ranged from 0.0 to $0.5 \%$ within E. amamiensis and from 0.0 to $2.1 \%$ within E. brevicornis (Table 2). There was no overlap between intraspecific and interspecific $p$-distances, but interspecific and intergeneric distances significantly overlapped in the histogram (Fig. 1B). This pattern was caused by the very deep interspecific divergence of E. amamiensis and E. brevicornis, which spanned a range of 22.7-23.9\% (Table 2). Similarly, each species formed a homogenous cluster well separated from all other taxa in the MDS ordination diagram inferred from the pairwise $p$-distances (Fig. 1C). Distances among individual species were comparable, documenting their deep genetic divergences as well. 
Haplotype network analyses supported the monophyletic origin of E. amamiensis and E. brevicornis by 55 shared nucleotide positions within the 567 nucleotides long barcoding COI sequence fragment. Specimens of the former species were separated by 1-3 mutation steps, while those of the latter species by 1-12 mutation steps. The two species of Elmomorphus differed by as many as 109 nucleotide positions, documenting their very deep genetic divergence (Fig. 2).

\section{A IQTrees/MrBayes/NJ}

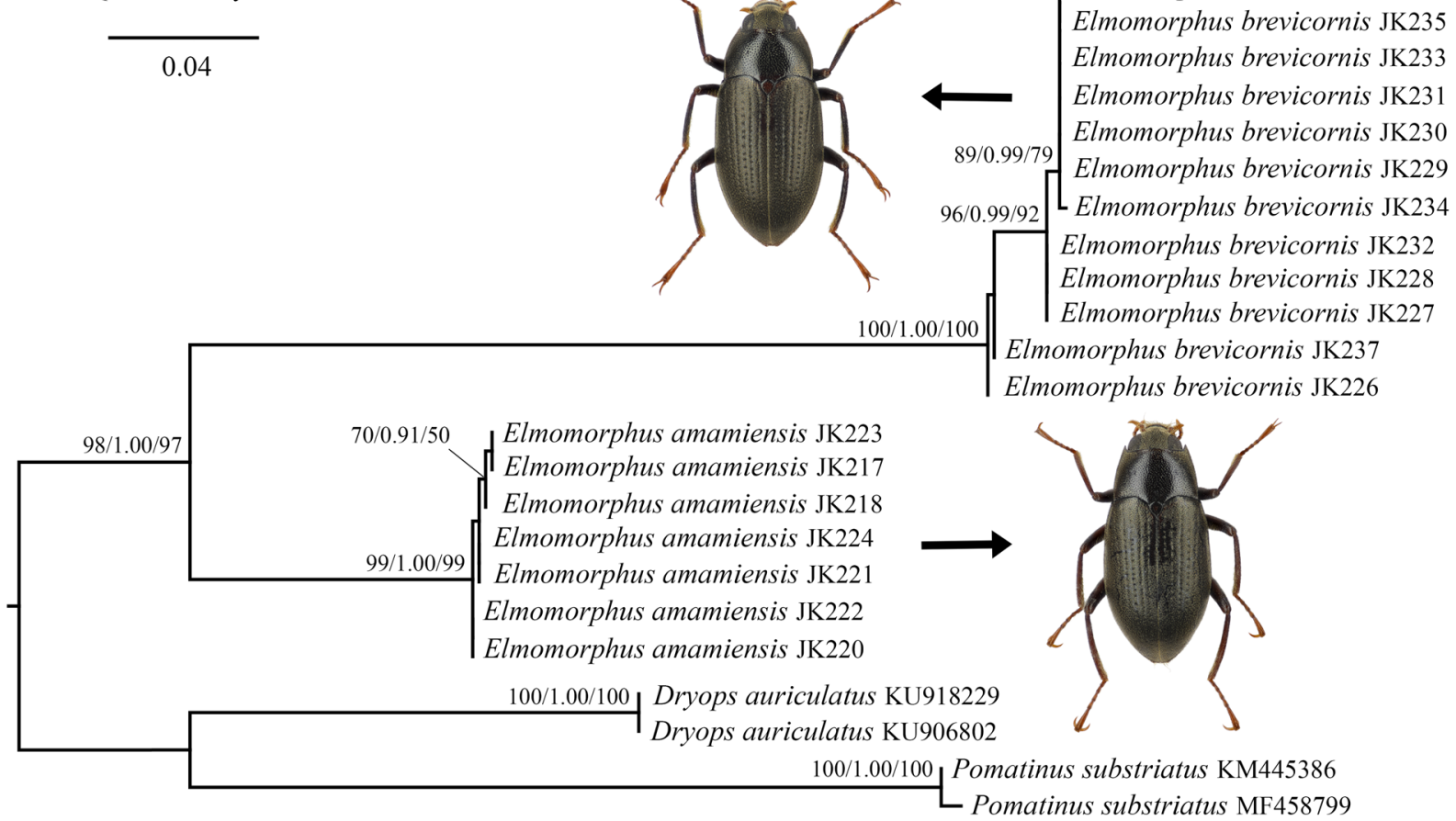

B Barcoding analysis

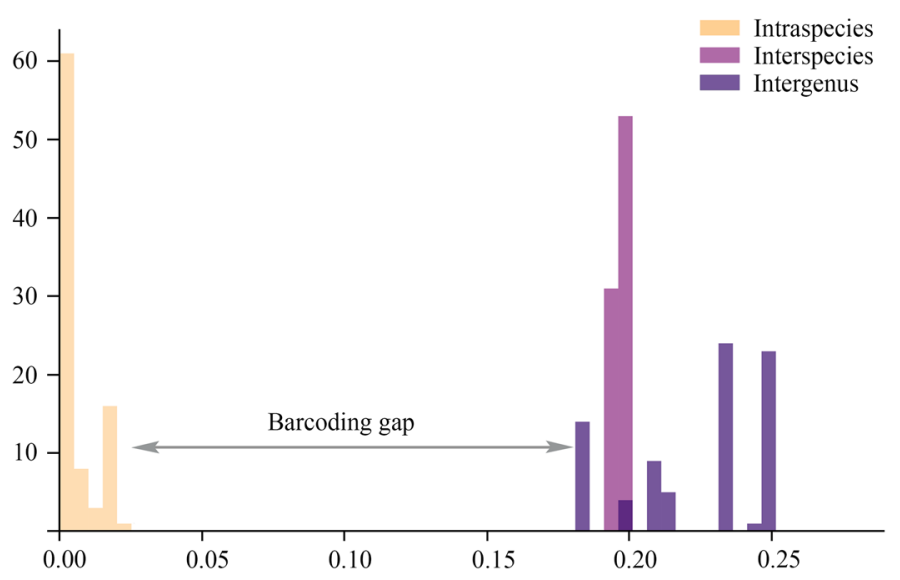

C Multidimensional scaling

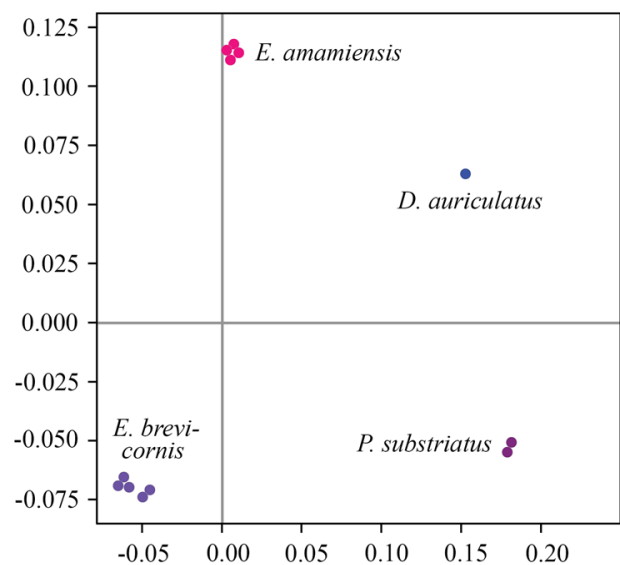

Fig. 1. Phylogenetic relationships and genetic distances between Japanese Elmomorphus species. Pomatinus substriatus (Müller, 1806) and Dryops auriculatus (Geoffroy, 1785) served as outgroup taxa in all analyses. A. Phylogenetic tree based on the mitochondrial COI gene. Bootstrap values for maximum likelihood analyses performed in IQTrees and distance NJ analyses performed in MEGA-X as well as posterior probabilities for Bayesian interference performed in MrBayes were mapped onto the best scoring IQTree. The scale bar denotes four substitutions per 100 nucleotide positions. B. Histogram displaying intraspecies, interspecies, and intrageneric distances of the taxa shown in (A). C. Multidimensional scaling based on $p$-distances of the taxa shown in (A). 


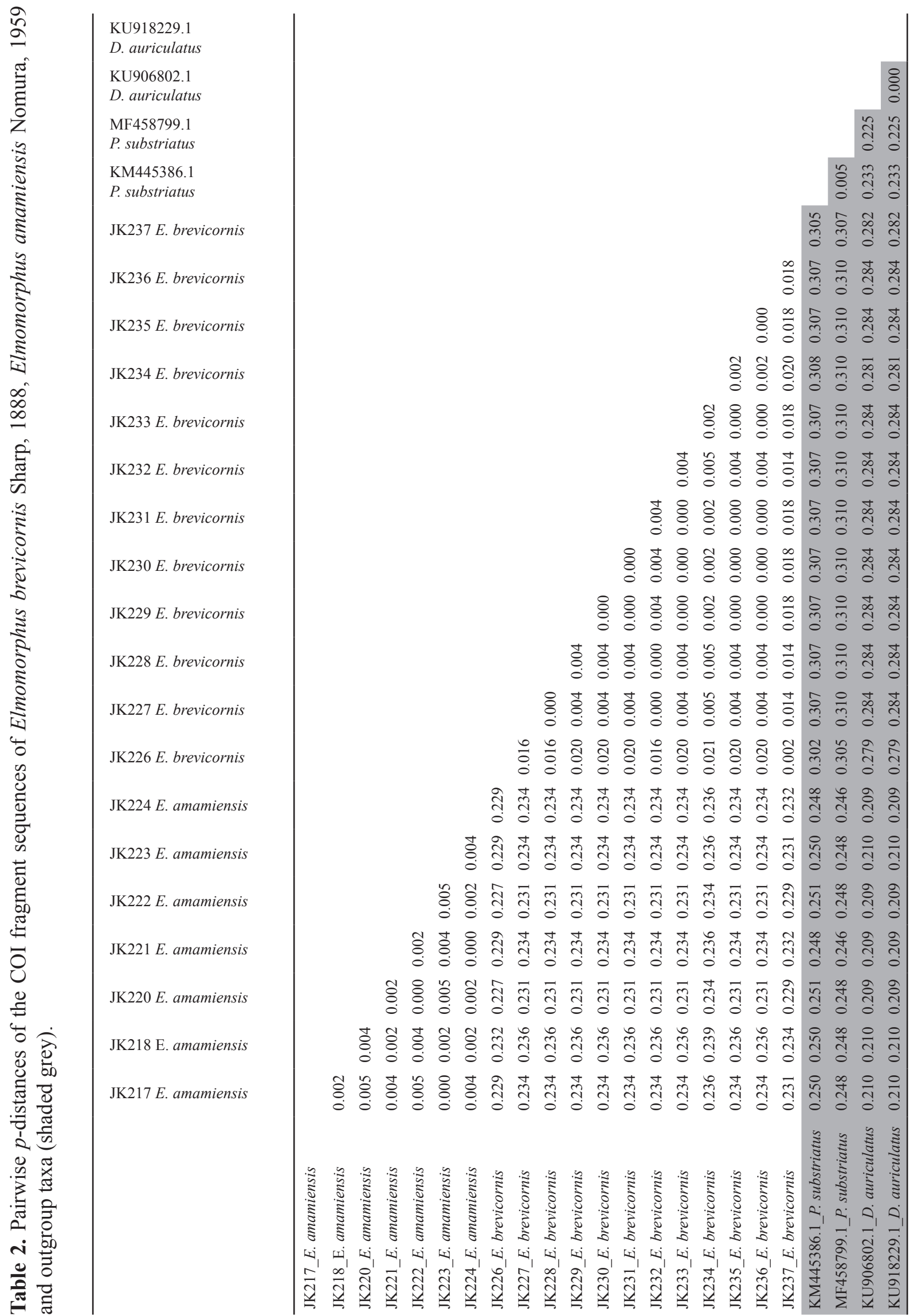




\section{Multivariate morphometric analyses}

To assess the morphometric variation of the two species, principal component analysis (PCA), based on eight morphometric characters, was carried out for each sex separately. In males, the first and second principal components (PC1 and $\mathrm{PC} 2$ ) explained $62.58 \%$ and $25.16 \%$ of the total variance, respectively. Two homogenous groups, each representing one species of Elmomorphus, were rather well separated along the first ordination axis (Fig. 3A). The pronotal length and width strongly correlated with PC1, while the length of meso- and metatibia with PC2 (Table 3). Thus, specimens with smaller bodies and longer tibiae are clustered in the upper left part of the ordination diagram, while individuals with larger bodies and shorter tibiae are placed in the lower right corner. These positions correspond well with raw measurements according to which the average body size of $E$. amamiensis males is smaller, while the tibiae of the males of E. brevicornis are on average longer. Although the average values are comparatively different, the character ranges overlap in the two species. Individual characters thus do not allow unambiguous identification. However, the combination of eight morphometric features can differentiate males of the two species without any overlap in the phenotypic space.

In females, $\mathrm{PC} 1$ and $\mathrm{PC} 2$ explained $77.92 \%$ and $8.93 \%$ of the total variance, respectively. Females of the two species of Elmomorphus were only vaguely separated along the first ordination axis, as two specimens of E. brevicornis were placed within the rather compact cluster of E. amamiensis individuals (Fig. 3B). The pronotal length and the elytral width strongly correlated with PC1, while the length of the protibia and the interocular distance correlated with PC2 (Table 3). The cluster of E. brevicornis

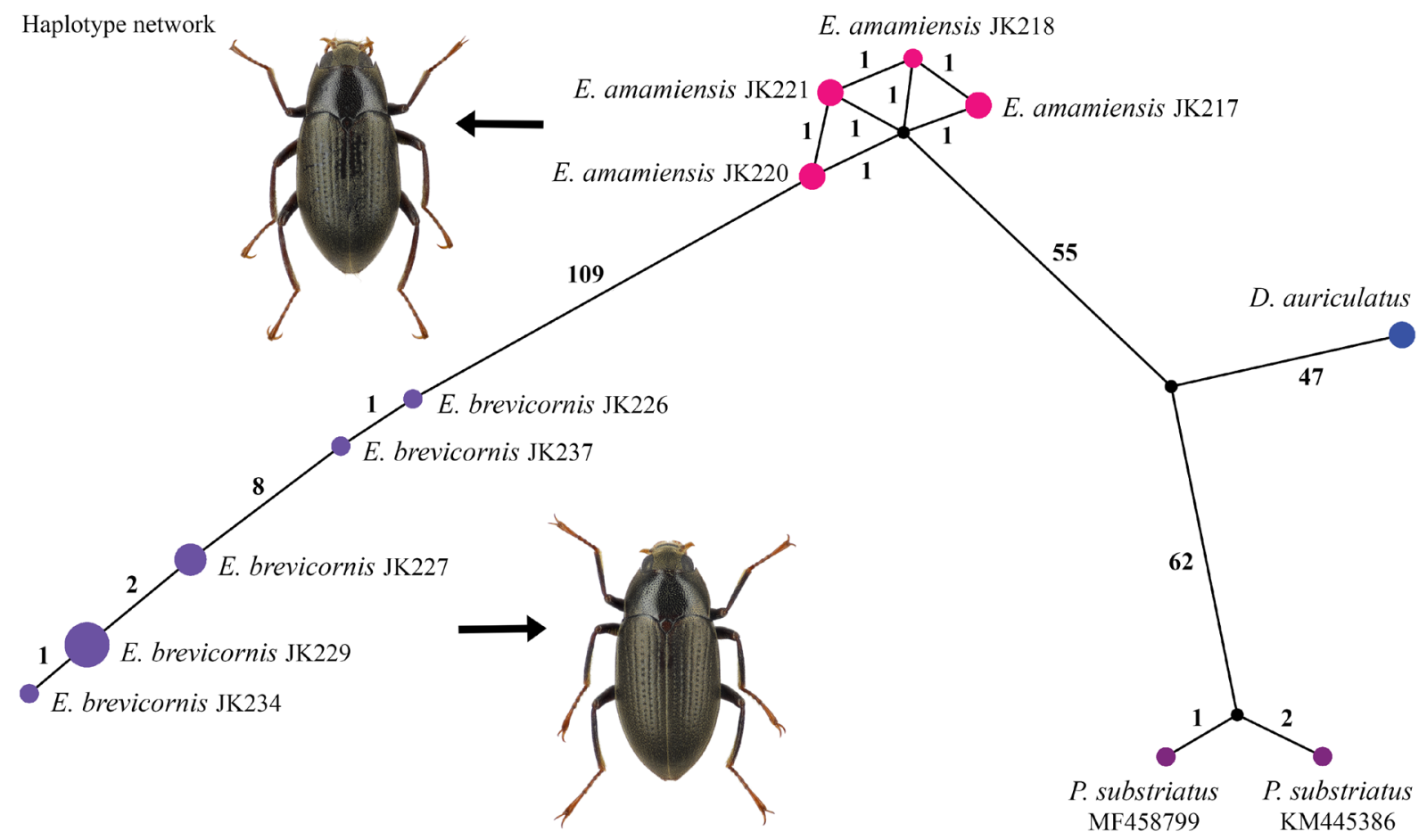

Fig. 2. TCS haplotype network of COI sequences of Elmomorphus brevicornis Sharp, 1888, Elmomorphus amamiensis Nomura, 1959 and two outgroup taxa. Numbers along edges represent mutational steps. For specimens belonging to individual haplotype groups, see Fig. 1A. 
Table 3. Explained variance and loadings onto the first three principal components for males and females of Elmomorphus brevicornis Sharp, 1888 and Elmomorphus amamiensis Nomura, 1959. Loadings with first and second highest absolute values in each component are in boldface.

\begin{tabular}{lllllll}
\hline & \multicolumn{3}{c}{ males } & & \multicolumn{3}{c}{ females } \\
\hline & PC 1 & PC 2 & PC3 & PC 1 & PC 2 & PC 3 \\
Explained variance (\%) & 62.58 & 25.16 & 4.70 & 77.92 & 8.93 & 5.48 \\
Loadings: & & & & & & \\
PL & $\mathbf{0 . 5 0 8}$ & 0.207 & -0.022 & $\mathbf{0 . 4 9 5}$ & -0.059 & $\mathbf{- 0 . 8 3 9}$ \\
PW & $\mathbf{0 . 5 4 3}$ & -0.266 & 0.008 & 0.361 & 0.162 & 0.149 \\
EL & 0.389 & -0.070 & $\mathbf{- 0 . 3 6 4}$ & 0.344 & 0.052 & 0.169 \\
EW & 0.413 & -0.241 & -0.253 & $\mathbf{0 . 4 0 6}$ & 0.402 & 0.119 \\
PrTL & 0.124 & 0.441 & 0.006 & 0.386 & $\mathbf{- 0 . 4 6 4}$ & 0.274 \\
MsTL & 0.096 & $\mathbf{0 . 5 0 1}$ & -0.056 & 0.310 & -0.225 & 0.097 \\
MtTL & 0.126 & $\mathbf{0 . 6 1 3}$ & -0.021 & 0.247 & -0.343 & $\mathbf{0 . 3 2 6}$ \\
ID & 0.291 & -0.046 & $\mathbf{0 . 8 9 4}$ & 0.190 & $\mathbf{0 . 6 5 0}$ & 0.202 \\
\hline
\end{tabular}

females showed a size gradient with the smallest specimens located in the left part of the ordination diagram, where they were mixed with $E$. amamiensis females. The present multivariate analyses show that females of the two species cannot be unambiguously differentiated even when a combination of eight morphometric characters is considered.
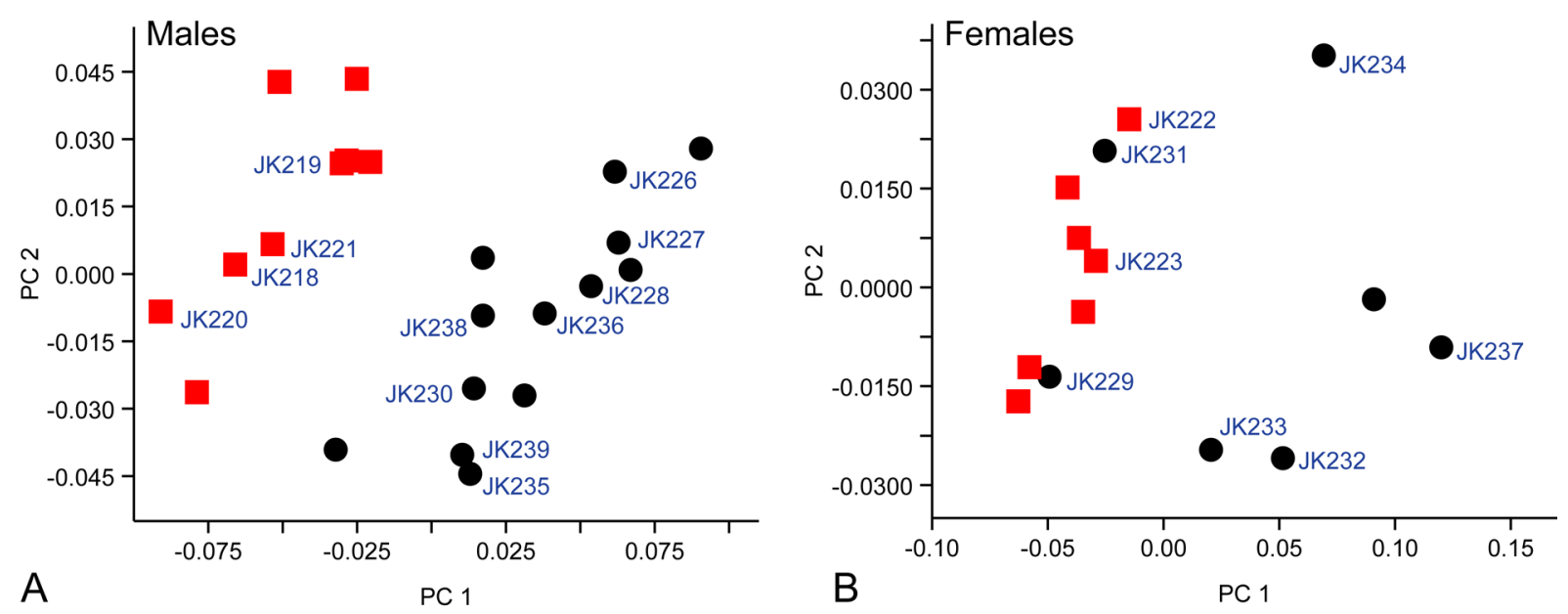

Fig. 3. Ordination of Elmomorphus brevicornis Sharp, 1888 (black circles) and Elmomorphus amamiensis Nomura, 1959 (red squares) along PC1 and PC2 axis. A. Males. B. Females. 


\section{Taxonomy}

Class Insecta Linnaeus, 1758

Order Coleoptera Linnaeus, 1758

Suborder Polyphaga Emery, 1886

Superfamily Byrrhoidea Latreille, 1804

Family Dryopidae Billberg, 1820

Genus Elmomorphus Sharp, 1888

Elmomorphus brevicornis Sharp, 1888

Figs 4A-C, 5A, 6A, C, E, 7A-D, 8A-B, E-F, 9A-B, D, 10A

Elmomorphus brevicornis Sharp, 1888: 243 (original description, type locality).

Helichus "862 spec. ?" Lewis 1879: 12 (first indication).

Elmomorphus brevicornis - Zaitzev 1910: 19 (catalogue). — Kôno 1934: 125 (catalogue). — Bollow 1940: 59-62, figs 271-276 (description, Japanese records). — Chûjô \& Satô 1964: 193. — Delève 1968: 151 (differential diagnosis). — Satô 1981: 53. — Jäch 1984: 314 (checklist). — Kodada \& Jäch 2006: 442 (catalogue). — Hayashi \& Shimada 2006: 129 (Japanese records, in Japanese). Yoshioka 2007: 236, 242, fig. 17a (Japanese records, in Japanese); 2008: 224 (Japanese records, in Japanese). - Hayashi 2011: 93. - Kamezawa \& Nomura 2013: 29 (Japanese records, in Japanese). - Jung \& Bae 2014: 2-7, figs 2a-c, 3-5 (description, identification key, Korean records). Kodada \& Jäch 2016: 606 (catalogue). - Yoshitomi \& Haga 2018: 341-342 (identification key). — Nakajima et al. 2020: 177, 322 (diagnosis, identification key, photographs of living specimens).

non Elmomorphus brevicornis - Devi et al. 2016: 371-373 (misidentification, invalid lectotype designation)].

\section{Type locality}

Kobe, Hyōgo Prefecture, southern Honshu, Japan.

\section{Material examined}

Syntypes

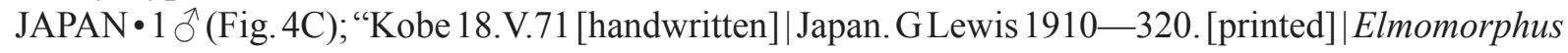
brevicornis [handwritten] | Elmomorphus brevicornis. [handwritten] | Elmomorphus brevicornis Sharp det. H. Bollow 1934 [handwritten and printed]"; NHMUK • 1 क (Fig. 4A-B); "Elmomorphus brevicornis Type D.S. [David Sharp] Jokio [sic]. Japan Lewis . [handwritten] | Japan. G.Lewis [printed] | Sharp Coll. 1905-313. [printed] | Type [printed, round label with red frame]"; NHMUK.

\section{Additional material}

JAPAN • 1 q; "Shimakatsu Mie-Pref. 16.XI.1958 Coll. Shozo Ishida |Elmomorphus brevicornis Sharp Det. M. SATO 1971"; NHMW • 1 ð’; "Nagara-River Gifu-City 26.VII.1951 Coll. Zen. Naruse"; NHMW

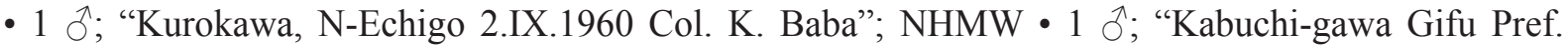

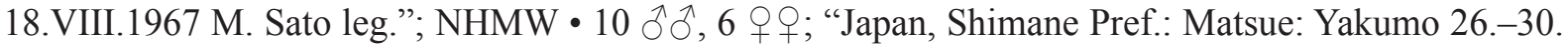

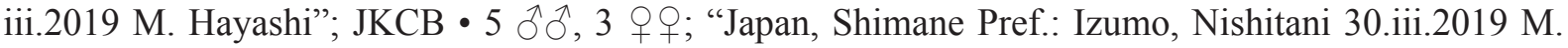
Hayashi”; JKCB • 1 क; "NE-JAPAN Miyagi Pr., Mts. Abukuma, 6.6. Uchikawa riv., leg. Ohmomo 1987 | Elmomorphus brevicornis Sharp"; NHMW.

SOUTH KOREA • 1 Oे, 1 spec. sex not examined; "South Korea, Jeollabuk-do, Buan-gun, Byeonsanmyeon, Junggye-ri, Jiko Falls 15.VI.2011, leg. S.W.Jung”; NHMW. 


\section{Note}

The original description was based on two specimens collected by G. Lewis. Both specimens are still preserved in the collection of David Sharp in the NHMUK. The female specimen is glued on a larger rectangular card with the following handwritten text: "Elmomorphus brevicornis Type D.S. Jokio. Japan Lewis.". This style of labelling and label text is typical of David Sharp's type material. The male specimen and the dissected aedeagus are glued on one card, while its detached appendages are glued on a second card, pinned below the specimen. The two syntypes are conspecific. However, while the type locality mentioned in the original description ("Kobé") is written on the original label of the male specimen (Fig. 4C), the name "Jokio" [Sharp's spelling of Tokyo] is found on the label of the female specimen (Fig. 4A). Since no other species is known from Honshu and since taxonomic confusion is improbable, a lectotype designation is considered unnecessary (see ICZN 1999: Recommendation 74G, https://www.iczn.org/the-code/declaration-44-amendment-of-article-74-7-3/).

In the abstract of their most remarkable article, Devi et al. (2016: 371) wrote that "A lectotype is designated for this species [Elmomorphus brevicornis]". However, the term "lectotype" is not used anywhere else in their article, and it does not contain sufficient information to ensure recognition of the specimen designated. Therefore, the requirements of the International Code of Zoological Nomenclature (ICZN 1999: Art. 74.7) are not fulfilled.
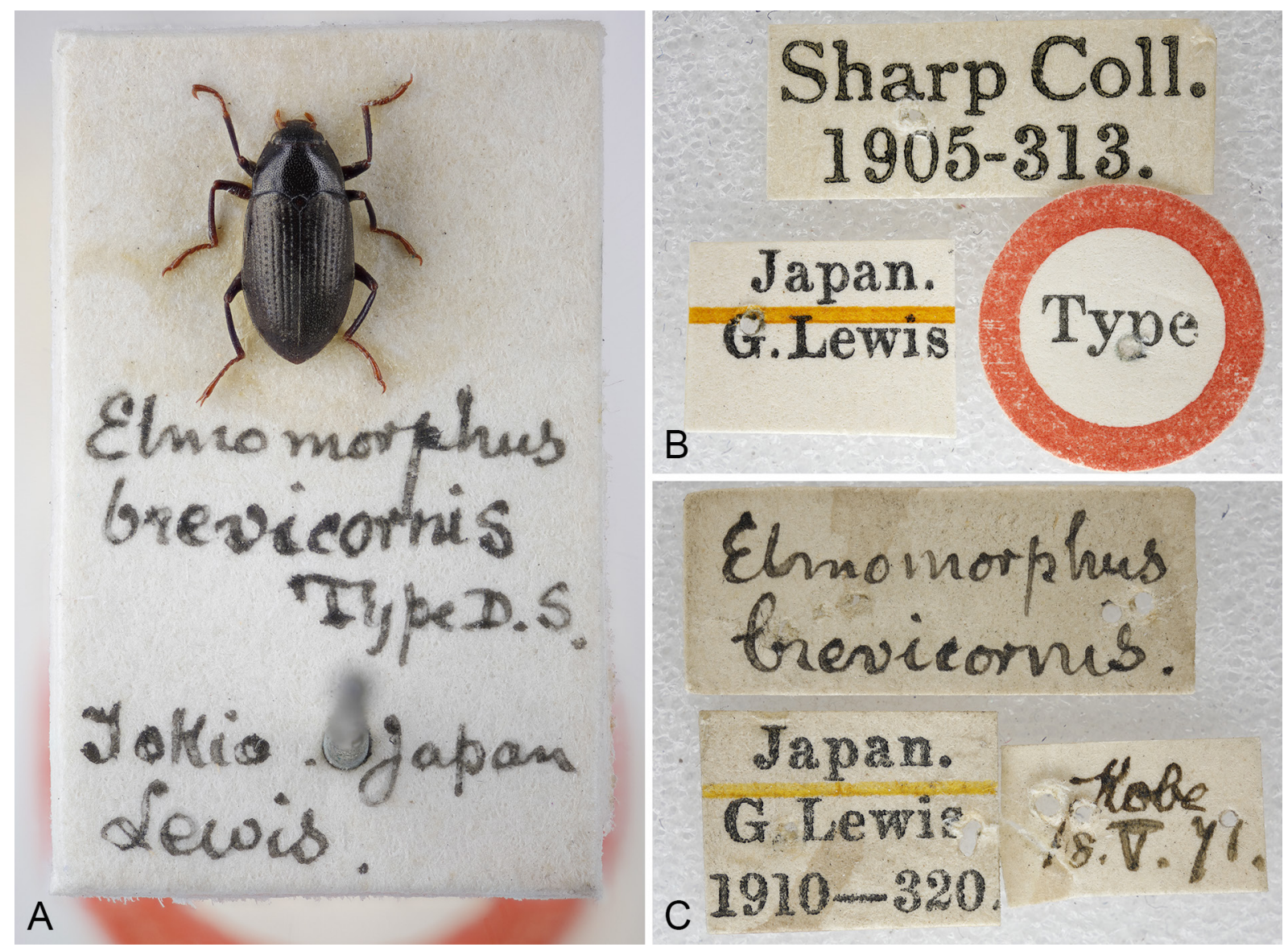

Fig. 4. Elmomorphus brevicornis Sharp, 1888. A-B. Syntype, $q$ (NHMUK). A. Specimen glued on the original card with Sharp's handwriting. B. Labels. C. Syntype, ô (NHMUK), labels (the last label not depicted). 


\section{Diagnosis}

Elmomorphus brevicornis is a medium-sized (TL 2.59-3.51 mm), elongated oval, dorsally moderately convex species, with the highest point at the anterior third of the elytral length (lateral view). Body outline discontinuous between pronotum and elytra; yellowish plastron microscales cover the entire surface of the cranium, lateral portions of the pronotum and the entire dorsal surface of the elytra, so most of the dorsal surface appears to be matt (Fig. 5A). Each elytron has nine rows of large round punctures arranged in shallow striae. Legs conspicuously long and robust, only moderately shorter than the combined length of pronotum and elytra.

Elmomorphus brevicornis closely resembles E. amamiensis in external morphology, and it can be distinguished by the following characteristics: (1) elytral sides in E. brevicornis subparallel in the anterior half, while in E. amamiensis they are arcuate and more convergent (Fig. 5B), thus the outline appears to be generally broader and less oval in E. brevicornis; (2) sides of pronotum usually more rounded in E. brevicornis, while they are almost straight in E. amamiensis; (3) males of E. brevicornis with several longer setae in a transverse row on the labrum, and with similar setae in two pairs of clusters on each prosternal process and on the admedian portions of metaventrite, row and clusters of setae rather inconspicuous (Fig. 6A, C, E); similar, longer setae also near the apex of the fifth ventrite (Fig. 7D); in the male of $E$. amamiensis the setal row and all setal clusters are well developed, conspicuous (Figs 6B, D, F, 7E); (4) parameres weakly curved ventrad in E. brevicornis (Fig. 8B), but strongly curved in E. amamiensis (Fig. 8D); (5) bursa copulatrix of the two species distally with one cluster of microspines on each side (Fig. 9D), while in E. amamiensis, besides these microspines there are several additional larger sclerites (Fig. 9E). Except for differences in the morphological characters, the two species differ by $22.7-23.9 \%$ in the partial mtDNA encoding for cytochrome $c$ oxidase subunit I.

\section{Measurements (mm)}

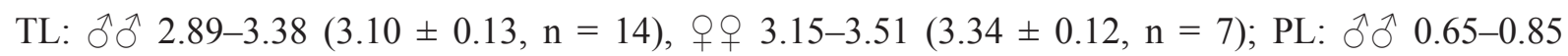

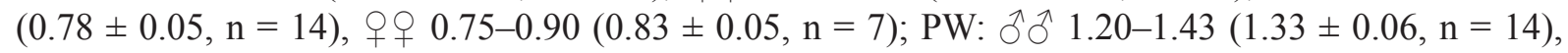

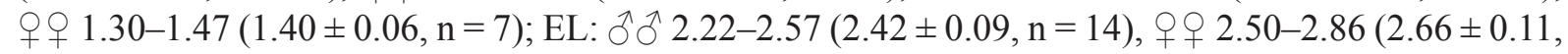

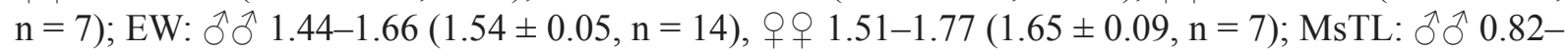

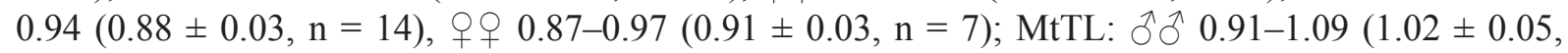
$\mathrm{n}=14)$, 우 0.97-1.12 (1.06 $\pm 0.05, \mathrm{n}=7)$; PhL: 0.73-0.89 $(0.83 \pm 0.04, \mathrm{n}=11)$; PrL: $0.32-0.39$ $(0.37 \pm 0.02, \mathrm{n}=11)$.

\section{Redescription}

Body. Elongated oval, widest behind mid-length of elytra, moderately convex dorsally, with the highest point at anterior third of elytral length (lateral view). Colouration black, except reddish-brown mouthparts, antennal clubs, tarsi, claws, trochanters, and ventral portions of femora. Tibiae and remainder of femoral surface dark brown to black. Dorsal pubescence consists mainly of short, thin decumbent yellowish setae arising from small punctures. Plastron microscales (Fig. 7B) on the entire cranium, on pronotum in two lateral bands, covering ca 0.2 of pronotal width on each side, and on the entire surface of elytra. Ventral surface with dense, thin plastron hair-like setae (Fig. 7C) except for prosternal process and median part of metaventrite.

HEAD. Dorsally entirely covered with plastron scales and with round, setiferous punctures; puncture diameter ca $0.75 \times$ diameter of an eye facet, and their distance varies between $0.50-1.00 \times$ of a facet diameter. Labrum transverse, with anterior margin straight; anterolateral angles rounded; exposed portion microreticulate, with small setiferous punctures; two types of hair-like setae present, short decumbent setae on most of the surface, and several longer semi-erect setae in a hardly discernible transverse row near mid-length (Fig. 6A), setae nearly half as long as ID and more obvious in males (in older material 


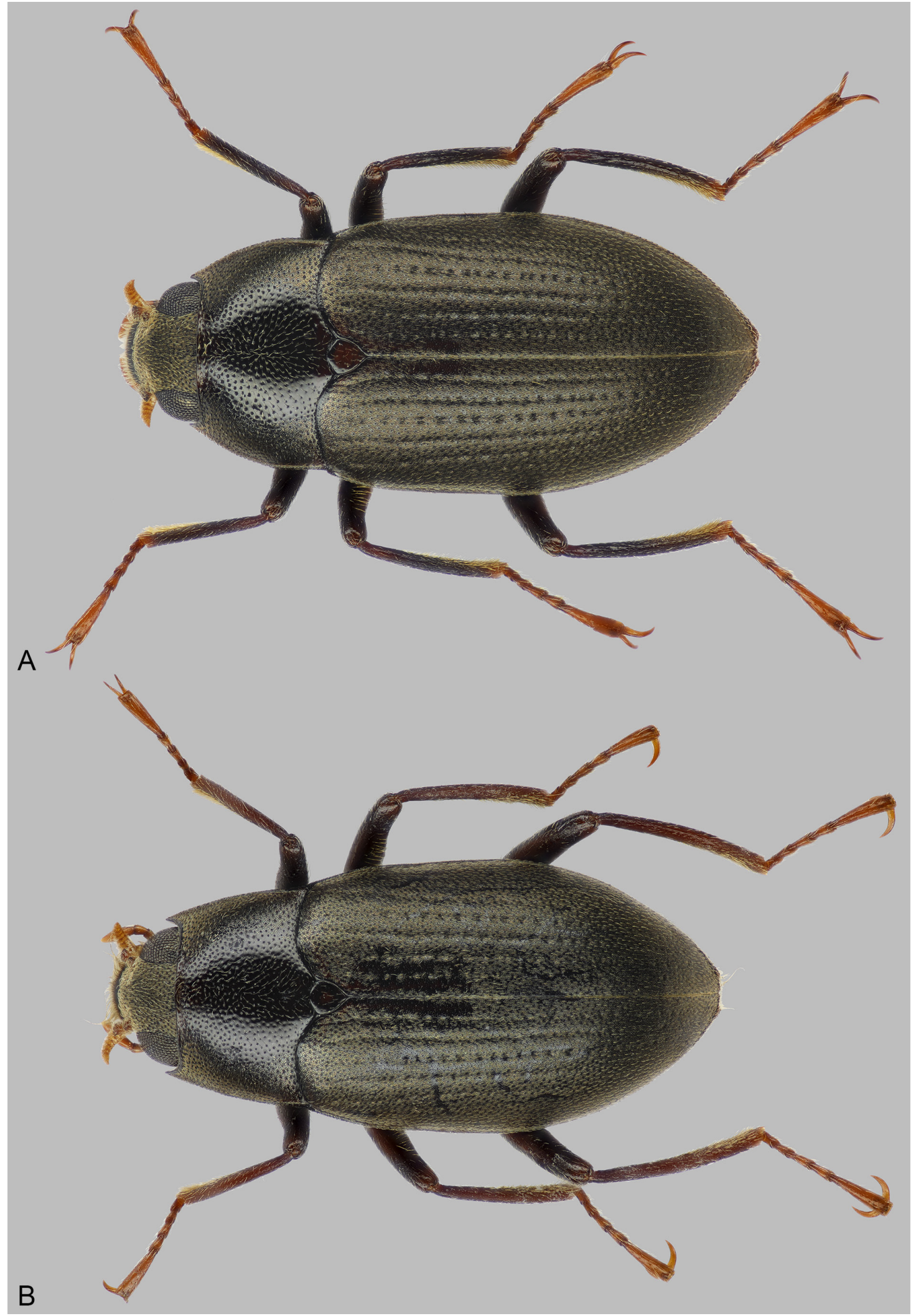

Fig. 5. Habitus. A. Elmomorphus brevicornis Sharp, 1888, Ô, length (anterior margin of clypeus to elytral apex): $3.7 \mathrm{~mm}$ (JKCB). B. Elmomorphus amamiensis Nomura, 1959, ô, length (anterior margin of clypeus to elytral apex): $3.4 \mathrm{~mm}(\mathrm{JKCB})$. 

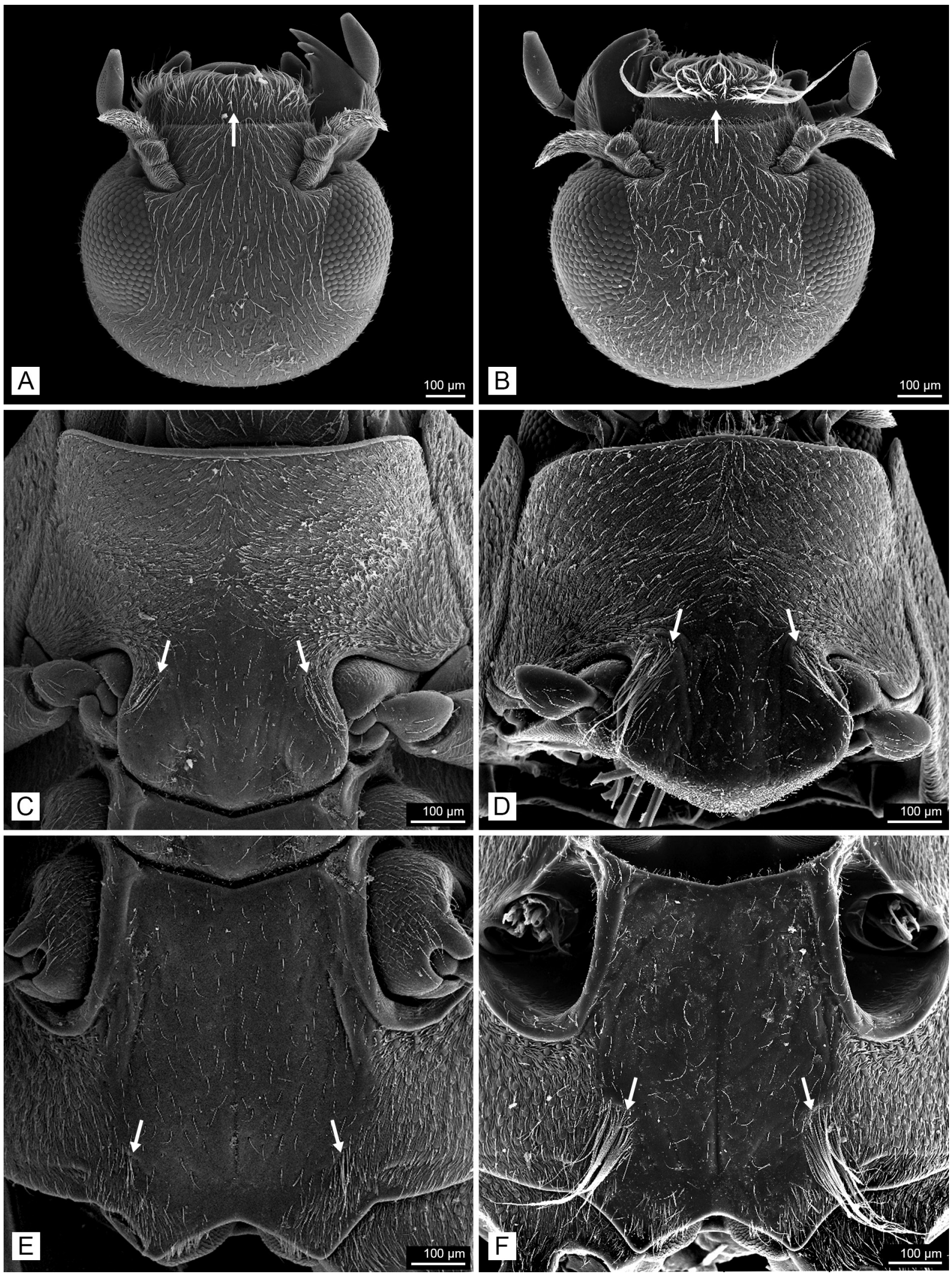

Fig. 6. Details of the male head and ventral portions. A, C, E. Elmomorphus brevicornis Sharp, 1888 (JKCB). B, D, F. Elmomorphus amamiensis Nomura, 1959 (JKCB). A-B. Head. C-D. Ventral view of the prothorax. E-F. Ventral view of the metathorax. Arrows show the position of setal clusters. 
long setae often abraded). Clypeus with anterior margin straight and with a row of the fine short hairs. Eyes oval, protruding and large, interfacetal setae short; ID: के के $0.38-0.43 \mathrm{~mm}(0.41 \pm 0.02, \mathrm{n}=14)$, 우우 0.42-0.48 mm $(0.44 \pm 0.02, \mathrm{n}=7)$; APD/ID: 줏 1.93-2.09 (2.01 $\pm 0.04, \mathrm{n}=14)$, 우우 1.89-2.04 $(1.96 \pm 0.05, \mathrm{n}=7)$. Antennae short, reaching slightly behind middle of eyes, 10 -segmented; densely covered by plastron; each club segment with a conspicuous peg-like sensillum on anterior face and numerous hair-like, peg-like and branched sensilla; scape and pedicel small and subequal in length, not enlarged.

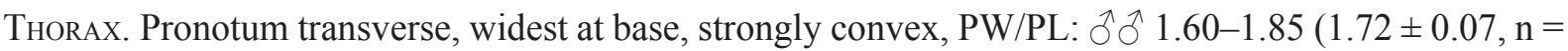
14), 우 우 1.60-1.76 $(1.68 \pm 0.05, \mathrm{n}=7)$; plastron in lateral band on each side along entire pronotal length, mesally reaching level of third elytral row; disc smooth, shiny, with large round setiferous punctures,
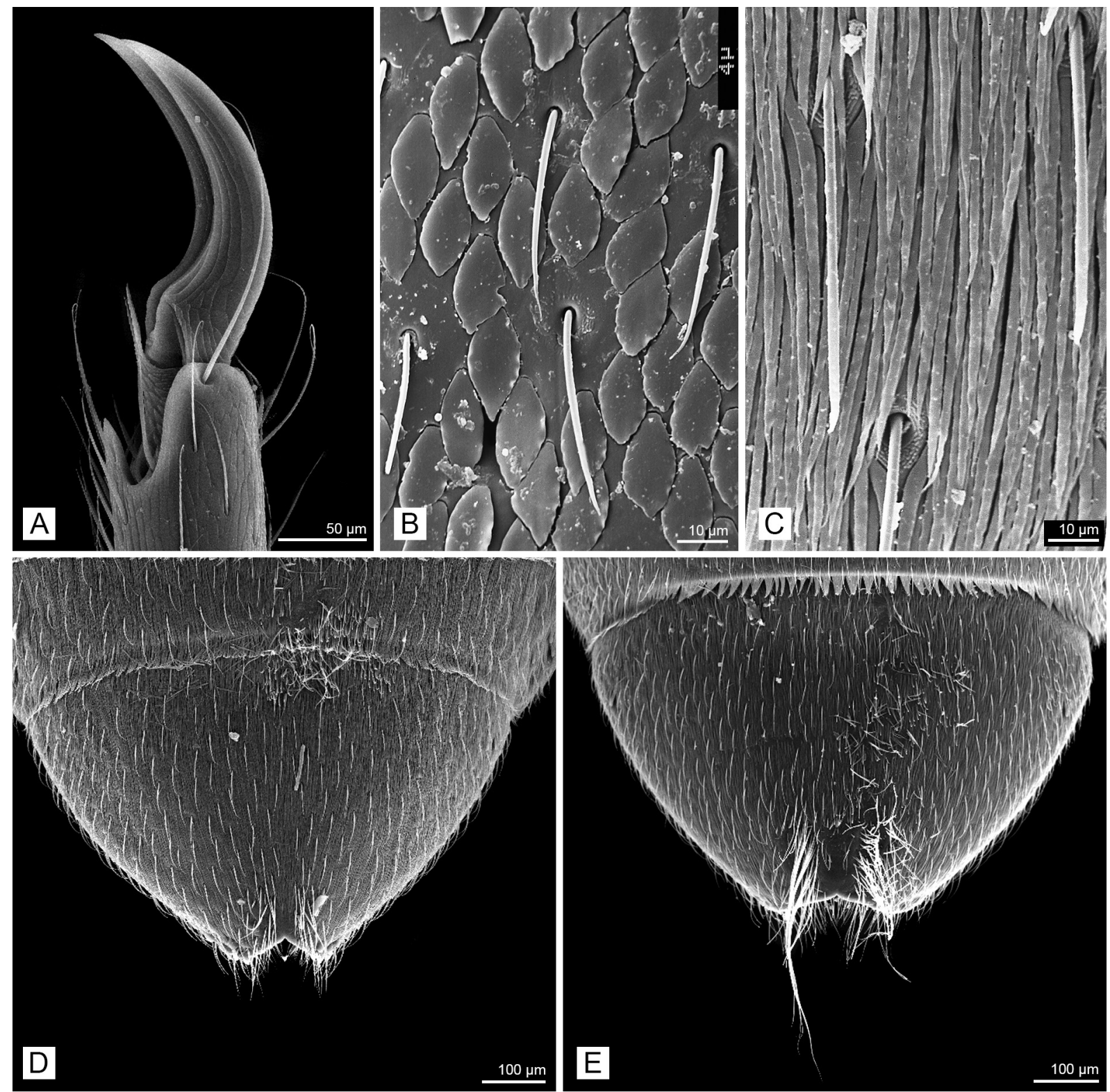

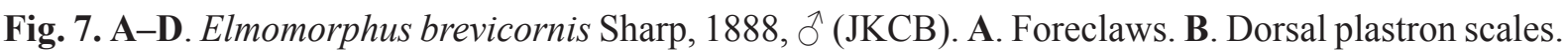
C. Ventral plastron scales. D. Detail on ventrite 5. E. Elmomorphus amamiensis Nomura, 1959, detail on male ventrite $5(\mathrm{JKCB})$. 
punctures nearly as large as facets, separated by $0.50-1.00 \times$ of a facet diameter; punctures on plastron area smaller, similar to those on head. Anterior angles strongly deflexed, protruding and acute, third as long as interocular distance; pronotal sides convergent anteriad, distinctly arcuate near middle, moderately explanate along entire length. Hypomeron widest behind mid-length. Prosternal process wide and short, lateral margins divergent and moderately arcuate; posterior margin widely rounded; lateral portion raised, wide and in male with group of longer setae (Fig. 6C) forming a hardly discernible setal cluster (these setae only moderately longer than other hair-like ventral setae and often abraded); median keel moderately convex, ca $1 / 3$ as wide as width of prosternal process. Scutellum longer than wide, smooth, with small, sparse punctures. Metaventral process with lateral sides strongly raised, anterior margin not raised. Metaventral disc flat in female, finely depressed in male; longitudinal step-like elevation along sides delimits lateral area with plastron from smooth central one, surface irregularly and moderately sparsely punctate and in some specimens finely irregularly wrinkled; discrimen well impressed, distinct; a small, hardly discernible setal cluster present in front of metakatepisternal suture in males on each side of metaventral disc (Fig. 6E). Elytra oblong, widest behind middle; moderately convex dorsally, in dorsal view with the highest point at anterior third; sides subparallel in anterior half, more strongly

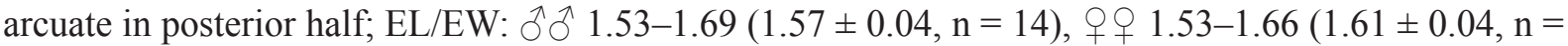
7); surface entirely covered by plastron scales and with numerous minute punctures distinctly smaller than a facet diameter, punctures separated by about $0.50-1.00 \times$ a facet diameter. Strial punctures large and deep on elytral disc and subequal in size with facet size, laterad and posteriad progressively smaller. All tibiae straight, to slightly bent near mid-length; protibia ca $1.25 \times$ as long as protarsus; PrTL/PL: ô $1.01-1.20(1.10 \pm 0.05, \mathrm{n}=14)$, 우 1.00-1.08 $(1.05 \pm 0.03, \mathrm{n}=7)$. Terminal tarsomere in male foreleg ca $1.20 \times$ as long as all preceding tarsomeres combined; male foreclaws strongly curved, not widened or thickened, about half of terminal tarsomere length, both similar to each other (Fig. 7A) and similar to female foreclaws.

ABDOMEN. All ventrites completely covered with plastron; ventrites $1-5$ with a length ratio about 1.00 : 0.76: 0.60: 0.40: 1.26 in male, and 1.00: 0.90: 0.73: 0.60: 1.60 in female; intercoxal process wide, about twice as wide as long, subtriangular, sides moderately arcuate; admedian keels feebly raised, reaching posterior margin of ventrite. Male ventrite 5 near anterior margin declivous and then shortly flattened, laterad and posteriad evenly deflexed; apex with distinct triangular excision (Fig. 7D); several longer semi-erect setae on each side of excision in hardly discernible clusters. Female ventrite 5 evenly convex and not flattened anteriorly, with minute longitudinal smooth keel at apex and few longer setae alongside keel; apex rounded. Sternite VIII moderately sclerotized laterally, membranous medially, in males with short strut on anterior margin (Fig. 8E), in females with strut almost as long as abdomen (Fig. 9A). Male sternite IX narrow, with sclerotized anterior strut (Fig. 8F). Aedeagus: phallobase long, narrow, expanded proximally (Fig. 8A), PhL/PrL: 2.14-2.36 (2.24 $\pm 0.07, \mathrm{n}=11)$; parameres slightly curved ventrad along apical half, nearly straight, with apices narrowly rounded (Fig. 8B); apex of penis slightly expanded and rounded in lateral aspect, not reaching apex of parameres; ventral sclerotized fibula absent. Ovipositor heavily sclerotized; right coxite ca 1.40× as long as left one; paraproct ca 1.80× as long as right coxite (Fig. 9B). Bursa copulatrix with a cluster of numerous minute spines arranged on each side of distal portions (Fig. 9D). Spermatheca tubular; accessory gland large, semi-tubular.

\section{Sexual dimorphism}

Females are, on average longer and broader than males. For an unambiguous distinction between males and females, the apex of the fifth ventrite should be examined: it is distinctly excised in males (Fig. 7D), while it is rounded, with a short, smooth keel in females. The presence of several longer semi-erect setae on the labrum, prosternal process, metaventral disc and on the apex of the fifth ventrite in males is hard to observe even in well-preserved specimens, and even under a high-quality microscope at a magnification of about $100 \times$. 

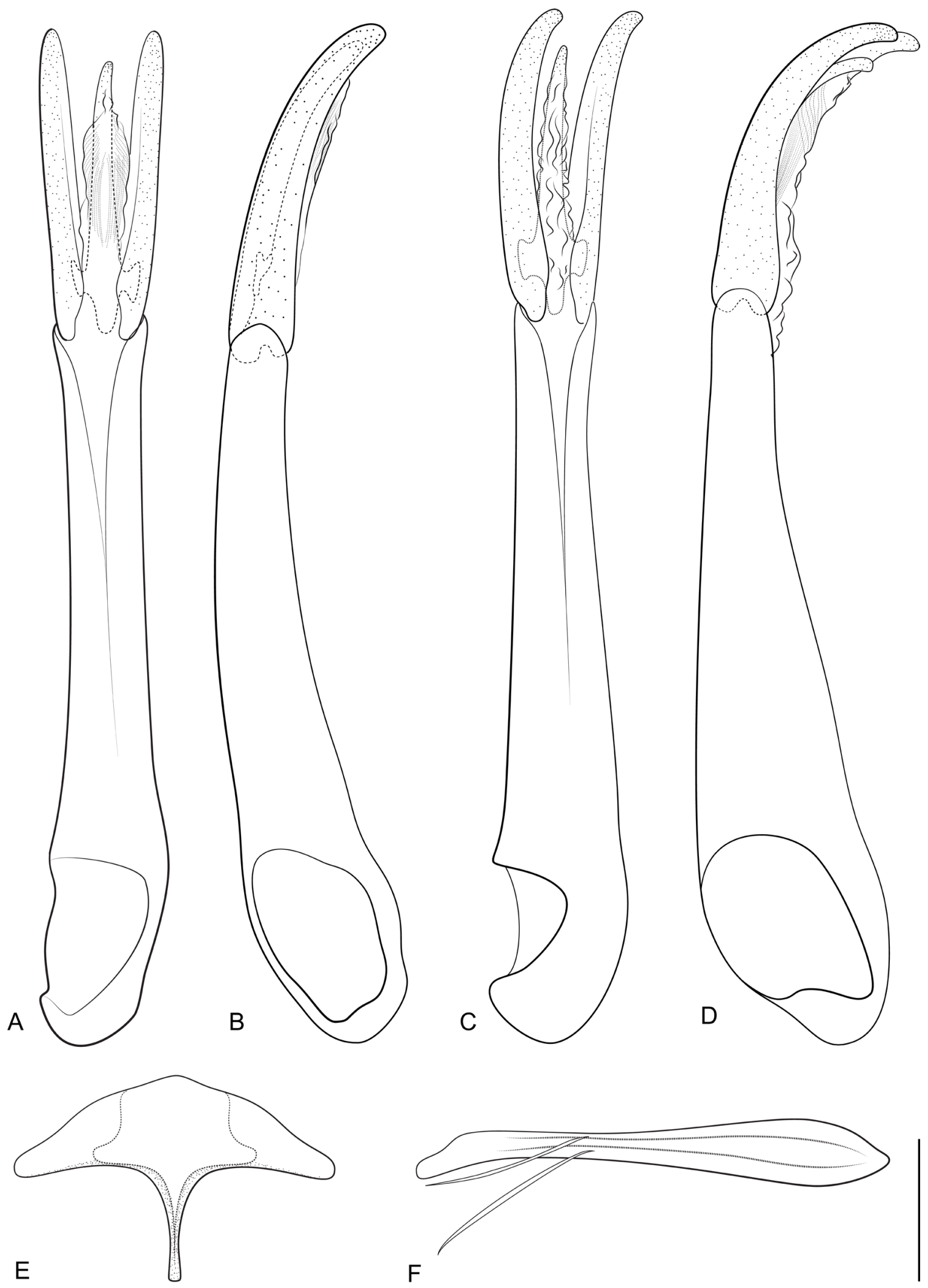

Fig. 8. Male terminalia. A-B, E-F. Elmomorphus brevicornis Sharp, 1888 (JKCB). A. Aedeagus, ventral aspect. B. Ibidem, lateral aspect. C-D. Elmomorphus amamiensis Nomura, 1959 (JKCB). C. Aedeagus, ventral aspect. D. Ibidem, lateral aspect. E. Sternite VIII. F. Sternite IX. Scale bar $=0.1 \mathrm{~mm}$. 


\section{Distribution}

Japan: Honshu, Izu-Ôshima, Oki, Shikoku, Kyushu, Tsushima, and Tanegashima (Nakajima et al. 2020); South Korea (Fig. 10A).

Devi et al. (2016) erroneously recorded E. brevicornis from India. Their record was published in the unreviewed "Journal of Entomology and Zoology Studies", a so-called predatory journal (see https://predatoryjournals.com/journals/). The "redescription" provided in this article does not allow any conclusions to be drawn on the identity of the specimens. The "Aedagues" [sic] depicted in their fig. 1c is, in fact, an ovipositor! Judging from their habitus photograph (fig. 1a), these specimens, beyond any doubt, do not belong to E. brevicornis or any other species similar to E. brevicornis.

\section{Immature stages}

The larva was described by Hayashi \& Kadowaki (2008) and Hayashi (2015). It was found in a river on submerged roots of Salix L. and Carex L. (Hayashi pers. com.).

Elmomorphus amamiensis Nomura, 1959

Figs 5B, 6B, D, F, 7E, 8C-D, 9C, E, 10B

Elmomorphus brevicornis amamiensis Nomura, 1959: 33 (original description).

Elmomorphus brevicornis amamiensis - Satô 1960: 252; 1965: 90; 1977: 1. — Kodada \& Jäch 2006: 442 (catalogue).

Elmomorphus amamiensis - Jung \& Bae 2014: 5 (new status, distribution). — Kodada \& Jäch 2016: 606 (catalogue). - Nakajima et al. 2020: 178, 322 (diagnosis, identification key, photographs of living specimens).

\section{Type locality}

Amami Island, Ryukyu Archipelago, Japan.

Type material (not examined)

See Jung \& Bae (2014: 5).

\section{Material examined}

JAPAN • 1 ô; "Amami-Ôshima Shinmura | 13. VI. 1962 M. Sato"; NHMW • 1 ơ; "(Ryukyus) Yona Okinawa 13.VIII.1969 Y. Hori leg."; NHMW • 1 ภ; "Nago-shi, Okinawa-ken 2-5.VIII.1980 Col. K. Baba|

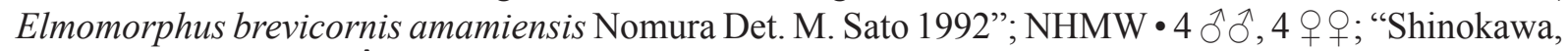
Setouchi-cho, Amami-Ôshima, Kagoshima, Japan, 28.22513, 129.29986, 5.III.2020, H. Yoshitomi leg.”; JKCB.

\section{Diagnosis}

Elmomorphus amamiensis is medium-sized (TL 2.80-3.22 mm), elongated oval, dorsally moderately convex, with the highest point slightly before the middle of the elytral length (lateral view); body outline slightly discontinuous between pronotum and elytra; plastron microscales covering the entire surface of the cranium, lateral portions of the pronotum and the whole dorsal surface of the elytra (Fig. 5B). Elytron with nine rows of moderately large, round punctures in shallow striae. Legs long and robust, somewhat shorter than the combined length of pronotum and elytra, claws moderately curved. Differences to the morphologically most similar E. brevicornis are discussed above. 
Measurements ( $\mathrm{mm})$

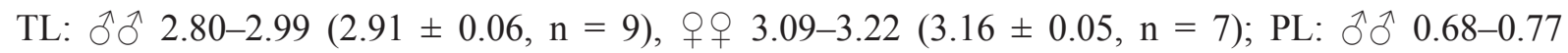
$(0.74 \pm 0.03, \mathrm{n}=9)$, 우우 0.70-0.78 $(0.76 \pm 0.03, \mathrm{n}=7)$; PW: ð̋

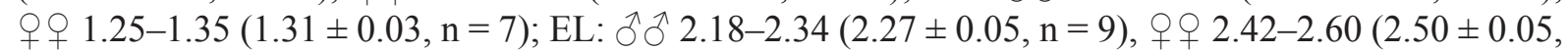

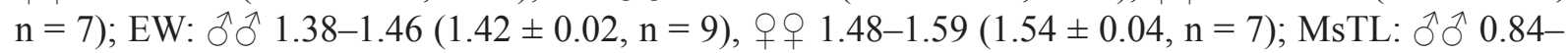
$0.96(0.92 \pm 0.03, \mathrm{n}=9)$, 우우 0.83-0.87 (0.85 $\pm 0.01, \mathrm{n}=7)$; MtTL: đ̋ 우우 0.99-1.04 (1.02 $\pm 0.02, \mathrm{n}=7)$; PhL: 0.91-1.19 (1.02 $\pm 0.08, \mathrm{n}=7)$; PrL: 0.39-0.43 (0.42 \pm 0.01 , $\mathrm{n}=7)$.

\section{Redescription}

Body. Elongated oval, widest behind mid-length of elytra, moderately convex dorsally. Colouration black; mouthparts, antennae, tibiae and tarsi reddish-brown; femora dark brown. Main pubescence consisting of very short and thin, decumbent yellowish setae, which arise from small punctures. Dorsal plastron present on the entire surface except for the pronotal disc. Ventral surface except for prosternal process and disc of metaventrite with hair-like plastron setae.

HEAD. With plastron and round setiferous punctures with a diameter of ca $0.75 \times$ a facet diameter, punctures separated by distance $0.50-1.00 \times$ a facet diameter. Labrum transverse, anterior margin straight, setose; anterolateral angles rounded; exposed portion microreticulate and micropunctate; male with a transverse row of strong, densely set conspicuous setae near middle (Fig. 6B), longest setae laterally, in
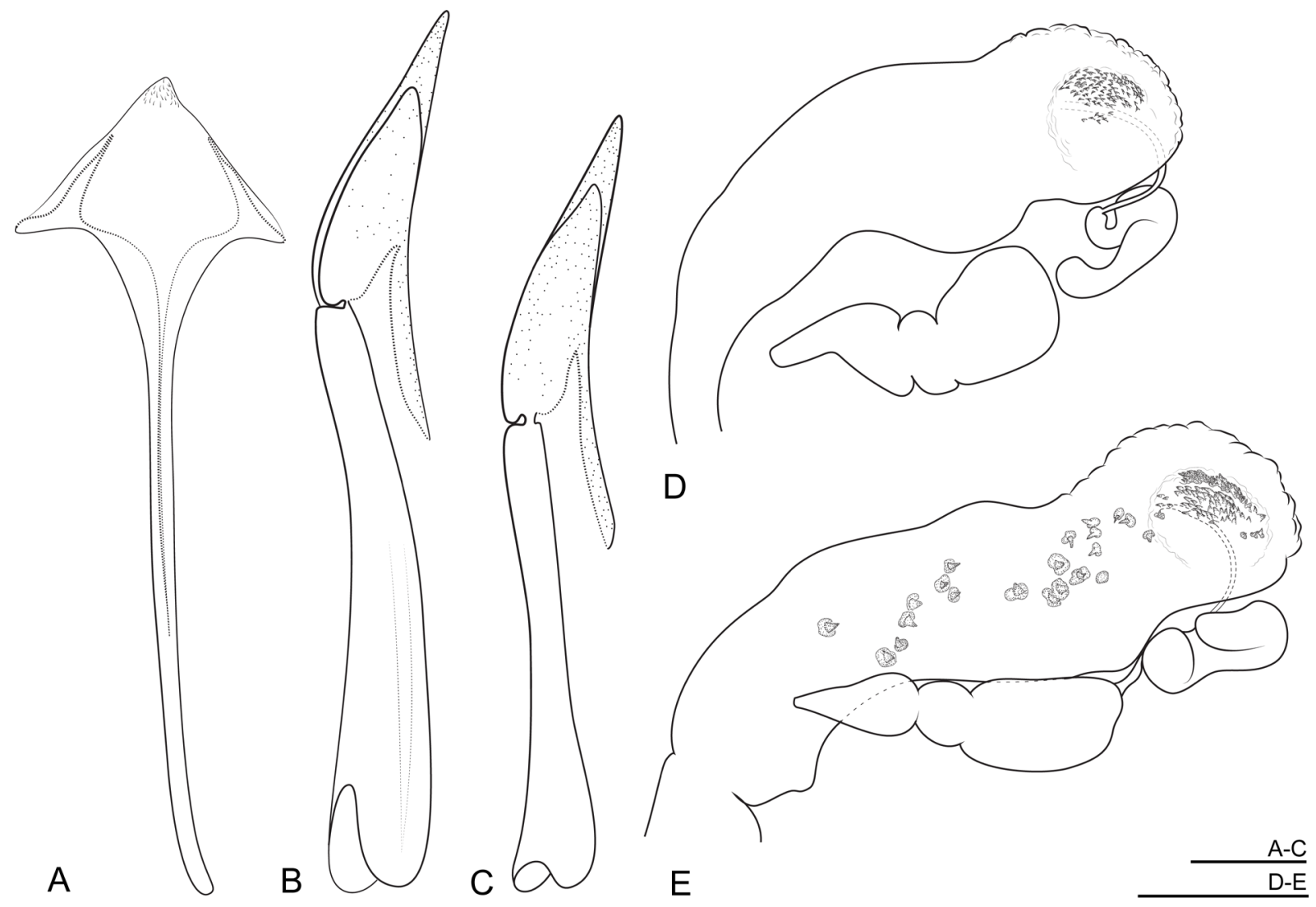

Fig. 9. Female terminalia. A-B, D. Elmomorphus brevicornis Sharp, 1888 (JKCB). A. Sternite VIII. B. Ovipositor. C, E. Elmomorphus amamiensis Nomura, 1959 (JKCB). C. Ovipositor. D. Bursa copulatrix. E. Bursa copulatrix. Scale bars $=0.1 \mathrm{~mm}$. 
length subequal to two-third of interocular distance; female with shorter and rather sparse setae, setal row hardly discernible. Anterior margin of clypeus straight, and not in the same plane as labrum. Eyes large, oval, protruding; interfacetal setae sparse, short; ID: $\delta^{\lambda} 0.37-0.43 \mathrm{~mm}(0.40 \pm 0.02, \mathrm{n}=9)$, 우우 $0.43-0.48 \mathrm{~mm}(0.44 \pm 0.02, \mathrm{n}=7)$. Antennae 10-segmented, shorter than eye length.

Thorax. Pronotum transverse, moderately convex, widest at base, PW/PL: $\hat{\jmath} \widehat{\jmath} 1.60-1.71(1.62 \pm 0.04$, $\mathrm{n}=9)$, 우 1.66-1.91 (1.73 $\pm 0.08, \mathrm{n}=7)$; plastron on entire lateral portions, mesally reaching level of third elytral row; pronotal disc smooth, with large, round setiferous punctures; punctures slightly smaller than facets, nearly regularly spaced, interstices $0.75-1.20 \times$ a facet diameter. Anterior angles strongly protruding, acute and deflexed; lateral sides of pronotum convergent anteriad, slightly arcuate or nearly straight, narrowly explanate. Prosternal process with lateral margins divergent, moderately arcuate; posterior margin rounded; lateral portion slightly elevated, separated from median keel by longitudinal depressions; median keel nearly flat, surface finely punctate and irregularly wrinkled. Male with two clusters of conspicuous long setae in anterolateral portions of prosternal process (Fig. 6D), longest setae as long as prosternum in front of prosternal process. Scutellum longer than wide, surface smooth, with small, sparse punctures. Metaventrite along middle ca twice as long as prosternal process; disc flat in males, slightly elevated in females, discrimen present nearly along the entire length, surface finely sparsely punctate, and irregularly wrinkled. Metaventral process as long as prosternal one, with lateral sides keel-like, anterior margin not straight, flat; male with two clusters of conspicuous long setae in posterolateral portions of metaventrite (Fig. 6F). Elytra ovate, widest behind middle; sides

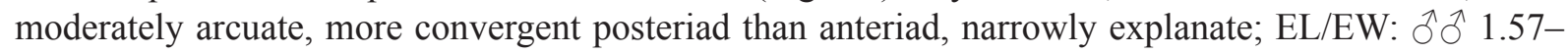
$1.64(1.60 \pm 0.02, \mathrm{n}=9)$, 우우 1.57-1.65 $(1.62 \pm 0.02, \mathrm{n}=7)$; entire surface with plastron; each elytron with nine striae, strial punctures smaller than facets, separated by distance of 1.00-2.00× puncture diameter; punctures smaller laterad and toward apex. Tibiae all straight, slender; protibia ca $1.25 \times$ as long as protarsus; PrTL/PL: đô 1.12-1.25 $(1.19 \pm 0.04, \mathrm{n}=9)$, 우 $1.03-1.21(1.09 \pm 0.05, \mathrm{n}=7)$. Terminal protarsomere in male ca $1.20 \times$ as long as all preceding tarsomeres combined; male foreclaws moderately curved, not widened or thickened, slightly less than half length of the terminal tarsomere length, both similar to each other and similar to female foreclaws.

AвDOMEN. Ventrites completely covered with plastron; ventrites 1-5 with length ratio 1.00: 0.74: 0.52: 0.48: 1.66 in male, and 1.00: 0.88: 0.65: 0.57: 1.84 in female. Intercoxal process wide, about twice as wide as long, subtriangular, sides distinctly arcuate; admedian keels indistinct, feebly raised in male, reaching posterior margin of ventrite, but nearly absent in female. Mesal portion of male ventrite 5 flattened on anterior third and strongly deflected posteriad (lateral view); apex with distinct triangular excision and cluster of several long semi-erect setae on each side of excision (Fig. 7E). Female ventrite 5 evenly convex and only indistinctly flattened anteriorly, with minute longitudinal smooth keel at apex and few longer setae alongside keel; apex rounded. Aedeagus: phallobase long, narrow, expanded proximally (Fig. 8C), PhL/PrL: 2.32-2.74 (2.43 $\pm 0.12, \mathrm{n}=7)$; parameres strongly curved ventrad, especially in apical half (Fig. 8D), moderately narrowed, apices subacute; penis with apex slightly expanded and rounded in lateral aspect; sclerotized fibula absent. Ovipositor heavily sclerotized; right coxite ca $1.30 \times$ as long as left one; paraproct ca $1.52 \times$ as long as right coxite (Fig. 9D). Bursa copulatrix with cluster of minute spines on each side of distal portions and with several larger sclerites scattered over proximal portion (Fig. 9E).

\section{Sexual dimorphism}

Females are on average larger than males, and the apex of their fifth ventrite is rounded, while in males it is triangularly excised. Moreover, males have long conspicuous setae arranged in a transverse row on the labrum and in clusters situated on lateral sides of the prosternal process, lateral sides of the metaventrite and on the apex of the fifth ventrite; females lack these groups of long setae. 


\section{Distribution}

Elmomorphus amamiensis has been so far recorded only from the Ryukyu Archipelago in Japan (Fig. 10B): Amami Island, Tokunoshima, Okinawa-jima, Iheya-jima, Zamami-shoto, Aka-jima, and Kume-jima (Nakajima et al. 2020).

\section{Key to the adults of the species of Elmomorphus from Japan and Korea}

1. Male labrum with several long, rather widely spaced setae arranged in a more or less distinct transverse row (Fig. 6A); similar, moderately longer setae arranged in small clusters on prosternal process and metaventrite (Fig. 6C, E), and on apex of ventrite 5 (Fig. 7D); long setae on labrum maximally half as long as interocular distance, most elongate ventral setae moderately shorter than those on labrum. Parameres in apical half slightly curved ventrad, nearly straight (Fig. 8B). Female: bursa copulatrix with a cluster of minute spines on each side in distal portions (Fig. 9D)

E. brevicornis Sharp, 1888

- Male labrum with numerous conspicuously long, closely arranged setae in a transverse row (Fig. 6B); similar setae in extensive clusters on prosternal process, metaventrite (Fig. 6D, F), and on apex of ventrite 5 (Fig. 7E); most elongate setae on labrum about $2 / 3$ of interocular distance, longest ventral setae moderately longer than interocular distance. Parameres in apical half strongly curved (Fig. 8D). Female: bursa copulatrix with cluster of minute spines and with several larger sclerites scattered over its proximal portion (Fig. 9E)

E. amamiensis Nomura, 1959

\section{Discussion}

Elmomorphus brevicornis has been recorded on six Japanese islands and has been quite recently, discovered in South Korea (Jung \& Bae 2014; Nakajima et al. 2020). Interestingly, an extensive collection of Elmomorphus specimens sampled during the China Water Beetle Survey from several hundred Chinese localities, including Taiwan, did not contain any specimens of E. brevicornis. Similarly, there have been no records from the Russian Far East, Vietnam, Laos, or Thailand. Therefore, E. brevicornis was for a long time considered to be an endemic species of Japan (Kodada \& Jäch 2006).

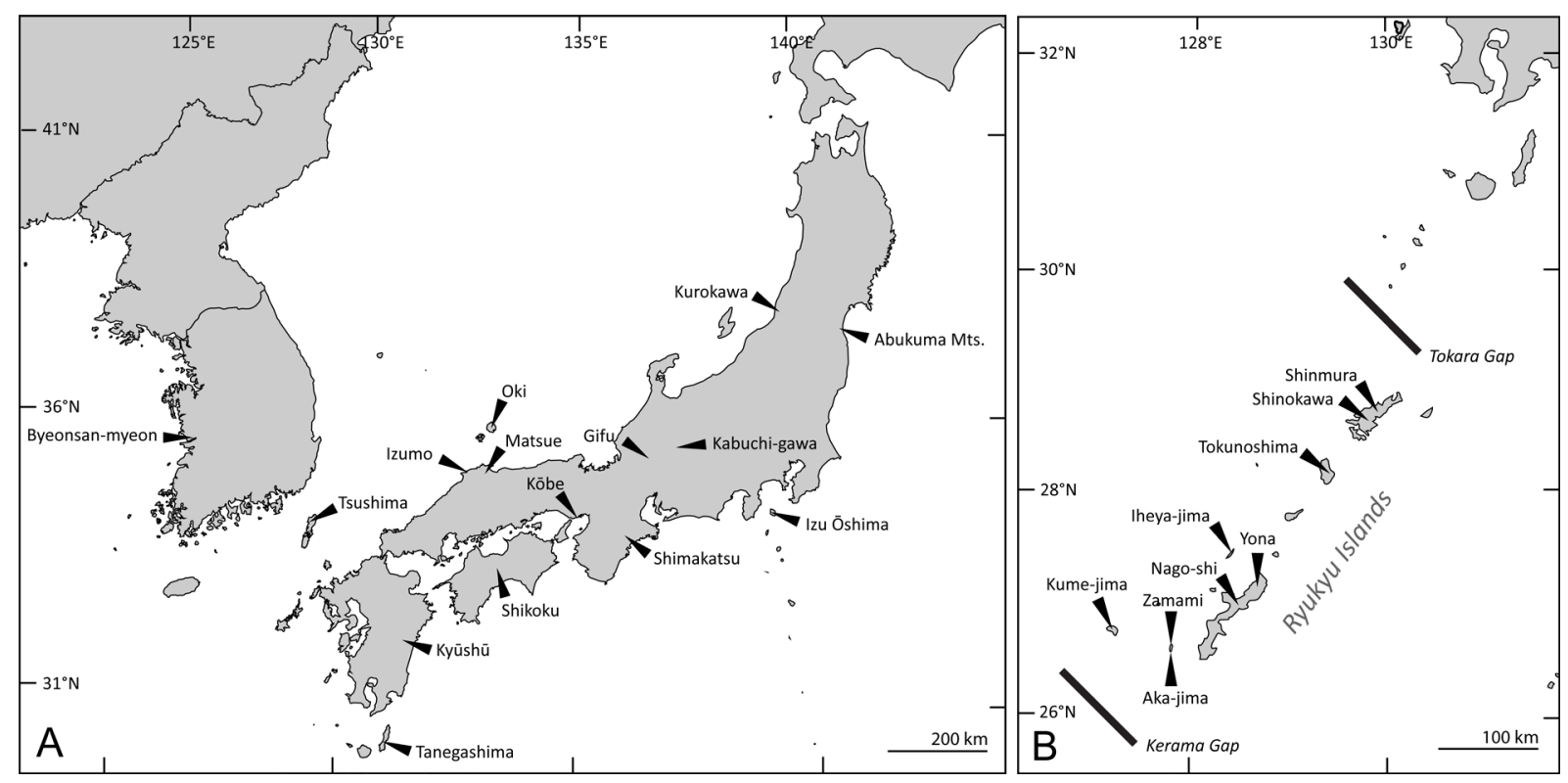

Fig. 10. Map showing records of A. Elmomorphus brevicornis Sharp, 1888. B. Elmomorphus amamiensis Nomura, 1959. 
The subspecies E. brevicornis amamiensis was established based on a female holotype collected on Amami-Ôshima, one of the largest islands of the Ryukyu Archipelago (Nomura 1959).

Jung \& Bae (2014) examined specimens of E. brevicornis from Korea and E. brevicornis amamiensis from Amami Island. Using differences in the structure of the male genitalia, they raised the subspecies amamiensis to species level. In their identification key, E. amamiensis was characterized by the long mesofemur, tarsi and claws small, and parameres strongly curved apically; while E. brevicornis possesses a shorter mesofemur, large tarsi and claws, and parameres, which are not strongly curved apically (Jung \& Bae 2014: 7).

The present principal component analysis classified males of the two species of Elmomorphus in two homogenous groups that were separated along the first ordination axis given the eight morphometric characters studied. The pronotal length and width are strongly correlated with PC1, while the length of meso- and metatibia are correlated with PC2. This corresponds well to raw measurements according to which the average body size of E. amamiensis males is smaller, while the average tibial length of E. brevicornis males is higher than in E. amamiensis. Although the average values are comparatively different, the ranges of individual characters overlap in the two species. Individual characters thus do not allow unambiguous species identification. However, the combination of eight morphometric features can differentiate males of the two species without any overlap in the phenotypic space. Females of the two species were only vaguely separated along the first ordination axis, as two specimens of E. brevicornis were placed within the relatively compact cluster of $E$. amamiensis individuals. The present multivariate analyses show that females of the two species cannot be unambiguously differentiated even when a combination of eight morphometric characters is considered. Nevertheless, we cannot exclude that inclusion of a significantly larger number of individuals from a wider distributional area into multivariate analyses might bring moderately different results. So far, the best characters for species identification of males are the conspicuous long hair-like setae on the labrum, prosternal process, metaventrite, and on the fifth ventrite in combination with the specific form of the parameres. Females can be distinguished by the different patterns of various sclerites on the bursa copulatrix.

Contrary to the morphological similarity between the two species, the present barcoding analyses show a profound interspecific divergence of E. amamiensis and E. brevicornis and confirm their species status as proposed by Jung \& Bae (2014). In addition, the haplotype network analyses supported the monophyletic origin of E. amamiensis and E. brevicornis by 55 shared nucleotide positions within the barcoding COI sequence fragment, although the two species differ in 109 nucleotide positions. This deep interspecific divergence is in congruence with the different geographic distribution of the two species. Elmomorphus amamiensis is confined to the Ryukyu Archipelago and has so far not been recorded north of the Watase Line (Tokara gap), a biogeographical barrier between the Holarctic and the Oriental regions, nor has it been found south of the Miyako Strait (Kerama gap) south of Okinawa. Thus, E. amamiensis represents one of the numerous endemic species of the Ryukyu Archipelago. On the other hand, E. brevicornis occurs north of the Tokara gap on several Japanese islands and in South Korea. The deep divergences within the COI sequences of the two Elmomorphus species suggest their different evolutionary origin rather than their sister-group relationship.

\section{Acknowledgements}

We would like to thank Hiroyuki Yoshitomi (Ehime University, Japan) and Masakazu Hayashi (Hoshizaki Green Foundation, Japan) for providing fresh material of both species, for comments on the manuscript as well as for the help in clarifying the distribution of the two species in Japan. We thank S.W. Jung (College of Life Sciences and Technology, Korea) for specimens of E. brevicornis from South Korea. We are grateful to Christine Taylor and Michael Geiser (both NHMUK, United Kingdom) for the loan of type specimens. Our thanks are also due to Alica Christophoryová (Comenius University in Bratislava, 
Slovakia) for her help in processing the habitus photographs and other illustrations. This work was supported by the Slovak Research and Development Agency under contract no. APVV-19-0076 and by the Grant Agency of the Ministry of Education, Science, Research and Sport of the Slovak Republic and Slovak Academy of Sciences (grant number VEGA 1/0515/19).

\section{References}

Bollow H. 1940. Monographie der palaearktischen Dryopidae mit Berücksichtung der eventuell transgredierenden Arten (Col.). Mitteilungen der Münchner Entomologischen Gesellschaft 30 (1): 24-71.

Chûjô M. \& Satô M. 1964. Family Dryopidae. In: Kira T. \& Umesao T. (eds) Nature and Life in Southeast Asia. Volume III: 193-194. Fauna and Flora Research Society, Kyoto.

Clement M., Posada D. \& Crandall K.A. 2000. TCS: a computer program to estimate gene genealogies. Molecular Ecology 9 (10): 1657-1659. https://doi.org/10.1046/j.1365-294x.2000.01020.x

Darriba D., Taboada G.L., Doallo R. \& Posada D. 2012. jModelTest 2: more models, new heuristics and parallel computing. Nature Methods 9 (8): 772. https://doi.org/10.1038/nmeth.2109

Delève J. 1968. Dryopidae et Elminthidae (Coleoptera) du Vietnam. Annales Historico-Naturales Musei Nationalis Hungarici 60: 149-181.

Devi M.B., Devi O.S. \& Wanghengbam L. 2016. Redescription of the first record of the species Elmomorphus brevicornis from the family Dryopidae (Coleoptera) in Manipur. Journal of Entomology and Zoology Studies 4 (3): 371-373.

Folmer O., Black M., Hoeh W., Lutz R. \& Vrijenhoek R. 1994. DNA primers for amplification of mitochondrial cytochrome c oxidase subunit I from diverse metazoan invertebrates. Molecular Marine Biology and Biotechnology 3 (5): 294-299.

Hammer Ø., Harper D.A.T. \& Ryan P.D. 2001. PAST: Paleontological statistics software package for education and data analysis. Palaeontologia Electronica 4 (1): 1-9.

http://palaeo-electronica.org/2001_1/past/issue1_01.htm

Hayashi M. 2011. Aquatic Coleoptera of Shimane Prefecture. Special Bulletin of the Hoshizaki Green Foundation 1: 1-117.

Hayashi M. 2015. Description of larva of Elmomorphus brevicornis Sharp (Coleoptera, Dryopidae). Bulletin of the Hoshizaki Green Foundation 18: 219-223. [In Japanese with English abstract.]

Hayashi M. \& Kadowaki H. 2008. Records on aquatic Coleoptera from rivers in and around Mt. Daisen, Tottori Prefecture, Japan, part II. Bulletin of the Hoshizaki Green Foundation 11: 269-286. [In Japanese with English abstract.]

Hayashi M. \& Shimada T. 2006. Records on Elmidae and Dryopidae from Eastern Area of Shimane Prefecture and Oki Islands, Japan. Bulletin of the Hoshizaki Green Foundation 9: 127-143. [In Japanese with English abstract.]

Hebert P.D.N., Cywinska A., Ball S.L. \& deWaard J.R. 2003. Biological identifications through DNA barcodes. Proceedings of the Royal Society B, Biological Sciences 270 (1512): 313-321.

https://doi.org/10.1098/rspb.2002.2218

Hoang D.T., Chernomor O., von Haeseler A., Minh B.Q. \& Vinh L.S. 2018. UFBoot2: improving the ultrafast bootstrap approximation. Molecular Biology and Evolution 35 (2): 518-522.

https://doi.org/10.1093/molbev/msx281

Hunter J.D. 2007. Matplotlib: a 2D graphics environment. Computing in Science and Engineering 9: 90-95. https://doi.org/10.1109/MCSE.2007.55 
ICZN 1999. International Code of Zoological Nomenclature. Fourth Edition. International Trust for Zoological Nomenclature, London.

Jäch M.A. 1984. Die Koleopterenfauna der Bergbäche von Südwest-Ceylon (Col.). Archiv für Hydrobiologie Supplement 69 (2): 228-332.

Jäch M.A. 1998. Annotated check list of aquatic and riparian/littoral beetle families of the world (Coleoptera). In: Jäch M.A. \& Ji L. (eds) Water Beetles of China, Volume II: 25-42. ZoologischBotanische Gesellschaft in Österreich and Wiener Coleopterologenverein, Vienna.

Jäch M.A. \& Balke M. 2008. Global diversity of water beetles (Coleoptera) in freshwater. In: Balian E.V., Levéque C., Segers H. \& Martens K. (eds) Freshwater Animal Diversity Assessment. Hydrobiologia 595 (1): 419-442. https://doi.org/10.1007/s10750-007-9117-y

Jung S.W. \& Bae Y.J. 2014. First record of the family Dryopidae (Coleoptera) in Korea with taxonomic notes on Elmomorphus brevicornis and Elmomorphus amamiensis. Animal Systematics, Evolution and Diversity 30 (1): 1-8. https://doi.org/10.5635/ASED.2014.30.1.001

Kamezawa H. \& Nomura S. 2013. Records of Elmomorphus brevicornis Sharp from Izu-Oshima, Izu Islands, Japan. Sabyabane, New Series 9: 29. [In Japanese.]

Kodada J. \& Jäch M.A. 2006. Family Dryopidae Billberg, 1820. In: Löbl I. \& Smetana A. (eds) Catalogue of Palaearctic Coleoptera. Volume 3. Scarabaeoidea, Scirtoidea, Dascilloidea, Buprestoidea, Byrrhoidea: 441-443. Apollo Books, Stenstrup.

Kodada J. \& Jäch M.A. 2016. Family Dryopidae Billberg, 1820 (1817). In: Löbl I. \& Löbl D. (eds) Catalogue of Palaearctic Coleoptera. Volume 3. Revised and updated edition. Scarabaeoidea, Scirtoidea, Dascilloidea, Buprestoidea and Byrrhoidea: 603-607. Brill, Leiden / Boston.

Kodada J., Jäch M.A. \& Čiampor F. 2016. 19.3. Dryopidae Bilberg, 1820 (1817). In: Beutel R.G. \& Leschen R.A.B. (eds) Coleoptera, Beetles. Volume 1: Morphology and Systematics (Archostemata, Adephaga, Myxophaga, Polyphaga partim), Handbook of Zoology, Arthropoda: Insecta: 590-602. $2^{\text {nd }}$ Ed. Walter de Gruyter, Berlin.

Kôno H. 1934. Die Dryopiden aus Japan. Insecta Matsumurana 8 (3): 124-128.

Kumar S., Stecher G., Li M., Knyaz C. \& Tamura K. 2018. MEGA X: Molecular Evolutionary Genetics Analysis across computing platforms. Molecular Biology and Evolution 35 (6): 1547-1549.

https://doi.org/10.1093/molbev/msy096

Leigh J.W. \& Bryant D. 2015. POPART: full-feature software for haplotype network construction. Methods in Ecology and Evolution 6 (9): 1110-1116. https://doi.org/10.1111/2041-210X.12410

Lewis G. 1879. A Catalogue of Coleoptera from the Japanese Archipelago. Taylor and Francis, London.

Miller M.A., Pfeiffer W. \& Schwartz T. 2010. Creating the CIPRES Science Gateway for inference of large phylogenetic trees. In: Proceedings of the Gateway Computing Environments Workshop (GCE): 1-8. IEEE, New Orleans, Louisiana. https://doi.org/10.1109/GCE.2010.5676129

Nakajima J., Hayashi M., Ishida K., Kitano T. \& Yoshitomi H. 2020. Dryopidae. In: Aquatic Coleoptera and Hemiptera of Japan: 177-179. Bun-ichi Sogo Shuppan, Tokyo. [In Japanese.]

Nguyen L.-T., Schmidt H.A., Haeseler A. von \& Minh B.Q. 2015. IQ-TREE: a fast and effective stochastic algorithm for estimating maximum-likelihood phylogenies. Molecular Biology and Evolution 32 (1): 268-274. https://doi.org/10.1093/molbev/msu300

Nomura S. 1959. Notes on the Japanese Dryopoidea (Coleoptera) II. Tôhô-Gakuhô 9: 33-38, 1 pl.

Pedregosa F., Varoquaux G., Gramfort A., Michel V., Thirion B., Grisel O., Blondel M., Prettenhofer P., Weiss R., Dubourg V., Vanderplas J., Passos A., Cournapeau D., Brucher M., Perrot M. \& Duchesnay É. 2011. Scikit-learn: machine learning in Python. Journal of Machine Learning Research 12: 2825-2830. 
Ronquist F., Teslenko M., Mark P. van der, Ayres D.L., Darling A., Höhna S., Larget B., Liu L., Suchard M.A. \& Huelsenbeck J.P. 2012. MrBayes 3.2: efficient Bayesian phylogenetic inference and model choice across a large model space. Systematic Biology 61 (3): 539-542.

https://doi.org/10.1093/sysbio/sys029

Satô M. 1960. Aquatic Coleoptera from Amami-Ôshima of the Ryukyu Islands (I). Kontyû 28 (4): 251254.

Satô M. 1965. Dryopoidea of the Ryukyu Archipelago, I (Coleoptera). Journal of the Nagoya Women's College 11: 76-94.

Satô M. 1977. Family Dryopidae. Check-List of Coleoptera of Japan 8: 1.

Satô M. 1981. Dryopidea (Coleoptera) of Nepal I. Family Dryopidae. Bulletin of Natural Science Museum Tokyo, Series A (Zoology) 7 (1): 51-56.

Sharp D. 1888. Descriptions of some new Coleoptera from Japan. Annals and Magazine of Natural History Series 6 2: 242-245. https://doi.org/10.1080/00222938809460918

Swan D.C. 1936. Berlese's fluid: remarks upon its preparation and use as a mounting medium. Bulletin of Entomological Research 27 (3): 389-391. https://doi.org/10.1017/S0007485300058259

Yoshioka M. 2007. Records on Dryopidae and Elmidae from water systems of Iinashi-gawa and Iu-gawa River, Eastern Area of Shimane Prefecture. Bulletin of the Hoshizaki Green Foundation 10: 235-256. [In Japanese with English abstract.]

Yoshioka M. 2008. Records on Dryopidae and Elmidae from water systems of Hakuta-gawa River and Hino-gawa River in San'in District, Japan. Bulletin of the Hoshizaki Green Foundation 11: 223-237. [In Japanese with English abstract.]

Yoshitomi H. \& Haga K. 2018. A new record of Dryops nitidulus (Coleoptera, Dryopidae) from Japan. Elytra, Tokyo, New Series 8 (2): 341-342.

Zaitzev P. 1910. Dryopidae, Cyathoceridae, Georyssidae, Heteroceridae. In: Schenkling S. (ed.) Coleopterorum Catalogus 17: 1-68. W. Junk, Berlin. Available from

https://www.biodiversitylibrary.org/item/189656\#page/3/mode/1up [accessed 4 Jun. 2021].

Manuscript received: 16 November 2020

Manuscript accepted: 13 April 2021

Published on: 8 July 2021

Topic editor: Nesrine Akkari

Section editor: Max Barclay

Desk editor: Pepe Fernández

Printed versions of all papers are also deposited in the libraries of the institutes that are members of the EJT consortium: Muséum national d'histoire naturelle, Paris, France; Meise Botanic Garden, Belgium; Royal Museum for Central Africa, Tervuren, Belgium; Royal Belgian Institute of Natural Sciences, Brussels, Belgium; Natural History Museum of Denmark, Copenhagen, Denmark; Naturalis Biodiversity Center, Leiden, the Netherlands; Museo Nacional de Ciencias Naturales-CSIC, Madrid, Spain; Real Jardín Botánico de Madrid CSIC, Spain; Zoological Research Museum Alexander Koenig, Bonn, Germany; National Museum, Prague, Czech Republic. 